\title{
Article
}

\section{Theaters of Proof: Visual Evidence and the Law in Call Northside 777}

\section{Jennifer L. Mnookin* and Nancy West**}

The year was 1932. Crime in Chicago had increased sharply during Prohibition, and the city denizens were anxious. On a cold and blustery Friday afternoon in December, two men entered a speakeasy and held its owner up at gunpoint. ${ }^{1}$ Shots were fired, and a policeman who happened to be present ended up dead-the eighth Chicago policeman to suffer a violent end that year. ${ }^{2}$ Another policeman murdered in broad daylight and

* Associate Professor, University of Virginia School of Law. Thanks to Jonathan Cannon, Joshua Dienstag, Daryl Levinson, Jim Ryan, Stephen Robertson, and Bill Stuntz, as well as to participants in a Virginia summer workshop and attendees at a panel at the Modern Language Association annual meeting for helpful comments. Thanks also to Fred Blumberg and Laura Kelly for useful research assistance.

** Associate Professor, Victorian and Cultural Studies, University of Missouri-Columbia. Thanks to Penelope Pelizzon and Sandy Camargo for reading drafts of this Article.

1. People v. Majczek, 195 N.E. 653, 654 (IIl. 1935).

2. Jack McPhaul \& James McGuire, Is He Guilty? Would You Convict Joe Majczek? Here's the Story Behind Slaying of Policeman, CHI. DAILY TIMES, Nov. 27, 1944, at 3. 
in cold blood? It was important that the public believe that the forces of law and order were still in control of the city. ${ }^{3}$ The police force and the residents of the city were hungry for justice, or at least vengeance. ${ }^{4} \mathrm{~A}$ Polish immigrant named Joseph Majczek was soon arrested for the murder, and a month later a co-conspirator was also charged. ${ }^{5}$ After an uneventful trial, they were both convicted of first-degree murder and sentenced to ninety-nine years in the Illinois State Prison. ${ }^{6}$ On appeal, their convictions were upheld. ${ }^{7}$ Case solved and case closed, or so it seemed. A short-lived blip on the front pages of the newspapers, this particular cop-killing was relegated to yesterday's headlines, the murder and the trial completely forgotten, at least in the popular imagination.

Eleven years later, however, the case became news once again. The convicted murderer's mother placed a classified ad in the Chicago Daily Times, offering a reward of $\$ 5000$ to anyone with information that could help set her son free. ${ }^{8}$ The ad caught the eye of a Times reporter, who, thinking there might be a "human interest" story in it, passed it to an editor who then assigned it to two members of his staff. ${ }^{9}$ These reporters published a series of investigative articles that generated widespread sympathy for Majczek and eventually led to his release and pardon. ${ }^{10}$ In 1948, the case was revisited again, this time by Twentieth-Century Fox in a film named Call Northside $777,{ }^{11}$ directed by Henry Hathaway and featuring James Stewart as an investigative reporter named P.J. McNeal, and Richard Conte as Frank Wiecek, the character based on Joseph Majczek. $^{12}$

3. See National Affairs: Illinois, TIME, Aug. 17, 1945, at 23 ("Mayor Anton Cermak, who was trying to get Chicago's mildewed reputation scrubbed up for the World's Fair, clamored for a crime cleanup.").

4. As McPhaul and McGuire wrote, "The period was one in which civic groups and newsgroups were agitated over a 'crime wave,' and the local papers were even publishing a 'daily score' on the state's attorney's accomplishments." McPhaul \& McGuire, supra note 2, at 3; see also JOHN J.

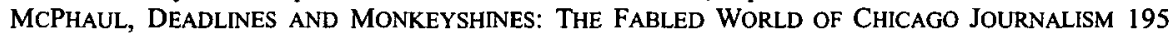
(1962) (describing how the mayor had ordered a no-holds barred "war on crime" in an effort to clean up the city for the upcoming Century of Progress Exposition).

5. Majczek, 195 N.E. at 655.

6. Id. at 654 .

7. Id.

8. CHI. Dally TIMES, Oct. 10, 1944, at 30. The ad read in full: " $\$ 5000$ Reward for killers of Officer Lundy on Dec. 9, 1932. Call Gro, 1758 12-7 p.m." Id.

9. Jack McPhaul \& James McGuire, Trial Witness Insists Identification False, CHI. DAILY TIMES, Nov. 28, 1944, at 3; see also MCPHAUL, supra note 4, at 191.

10. The series of articles began on November 27, 1944, and ran daily until December 5, 1944 . The Times continued to cover the case extensively through Majczek's eventual pardon on August 15, 1945.

11. CALl NORTHSIDE 777 (Twentieth-Century Fox 1948) [hereinafter Northside].

12. During the $1940 \mathrm{~s}$ and $1950 \mathrm{~s}$, Twentieth-Century Fox produced roughly thirty percent of all films now classified as "film noir" and nearly eighty percent of all films now classified as "noir documentaries," Northside among them. See AlaIN Silver \& ElizabETH Ward, FILM NoIR: AN ENCYCLOPEDIC REFERENCE TO THE AMERICAN STYLE 5 (1979). Other film noir titles produced by 
From a murder trial to a three-line advertisement to a Hollywood feature film: the trajectory of the Majczek case involves an explosion of narratives, each acquiring a greater mass audience than the one preceding it. This Article will focus on the film version, but we analyze the film in relation to the narratives that preceded, inspired, and shaped it-both the trial itself and the newspaper accounts that led to Majczek's freedom. For as we shall show, the film offers a sharp critique of legal rules of evidence, a critique that can best be understood in relation to the evidence presented in the actual Majczek trial. Moreover, through the vehicle of one particular wrongful conviction, the film attempts to tell a grander story of the power of mass media as a protector of freedoms and the righter of legal wrongs - just as the Chicago Daily Times's articles ended up not only freeing Majczek but winning awards for revealing the life-changing power of journalism at its best. ${ }^{13}$

Though it was both popular and critically acclaimed at the time of its release, Call Northside 777 is no longer much remembered. ${ }^{14}$ Today, it is typically a film consigned to a footnote in film history, not a minor film, but not a major one either. ${ }^{15}$ It enjoyed substantial popularity on its release, and it features one of Hollywood's most beloved actors; however, while Northside is available for rental at many video stores, it remains at

Fox include John Brahm's THE BRASHER DOUBLOON (Twentieth-Century Fox 1947), Henry Hathaway's THE DARK CORNER (Twentieth-Century Fox 1946), Otto Preminger's FALLEN ANGEL (Twentieth-Century Fox 1946), and LAURA (Twentieth-Century Fox 1944). For titles of noir documentaries produced by Twentieth-Century Fox, see infra note 16.

With directors like Preminger, Hathaway, and Robert Siodmak under contract, Twentieth-Century Fox could claim film noir and the noir documentary as being among its specializations. (Indeed, in a review of Northside, Time magazine called the studio "the leader" in making what it called "semidocumentary" films. New Picture: Call Northside 777, TIME, Feb. 16, 1948, at 99.) A relatively small studio compared to MGM or Paramount, Twentieth-Century Fox specialized in less popular and more "artsy" genres (as did RKO and Warner Bros.) rather than the big-budget musicals, dramas, and comedies that made the other studios so powerful. For discussion of the Hollywood studios and the types of films they made, see generally THOMAS SCHATZ, THE GENIUS OF THE SYSTEM: HOLLYWOOD FILMMAKING IN THE STUDIO ERA (1988).

13. McPhaul and McGuire won the annual Heywood Broun Award of the American Newspaper Guild for their reporting. MCPHAUL, supra note 4, between 180-81 (reprinting a photograph of the Heywood Broun Award at a Chicago Newspaper Guild ball in 1945). They also won several other awards, including one from the national journalism fraternity, Sigma Delta Chi, and one from the National Headliners Club. See Gary Houston, A Real Life Chicago Murder Mystery: Few Stories Compare with "Northside 777," CHI. TRIB., Jan. 9, 1995, at C1.

14. The L.A. Times, for example, called it "engrossing cinema[,] . . a a film triumph." Time magazine called it "a good answer to those who generalize too glibly about the superiority of European movies." New Picture: Call Northside 777, supra note 12, at 100.

15. In comparison to other films starring James Stewart, particularly those directed by Frank Capra and Alfred Hitchcock, Call Northside 777 has received scant popular or critical attention. More generally, Henry Hathaway has never enjoyed the kind of critical attention devoted to many other American directors. Despite a prolific career (he made sixty-one films between 1932 and 1971) and the critical and commercial success of many of his films, e.g., KISS OF DEATH (Twentieth-Century Fox 1947); HOW THE WEST WAS WON (MGM 1963); TRUE GRIT (Paramount 1969), no scholarly booklength study exists on Hathaway, and the Academy nominated him only once for Best Director-for Lives of a Bengal Lancer (Paramount 1935). See EMANuel LeVy, AND THE WinNer Is . . . : THE HISTORY AND POLITICS OF THE OSCAR AWARDS 170 (1987). 
best only vaguely familiar to most moviegoers. Scholars have paid Northside some limited attention, focusing primarily on its relation to film noir. ${ }^{16}$ But no full-length articles exist on Northside, and the rare discussions of it in film criticism are usually limited to a mere paragraph or two. ${ }^{17}$ What, then, justifies this Article? Is Northside worth so many

16. The three authors who engage with Call Northside 777 in most detail are film theorists J.P. Telotte and Frank Krutnik, and legal historian Norman Rosenberg. Rosenberg offers a rich analysis of Northside's themes, and he is the only author to date who emphasizes the ways that Northside represents "the law" as an institution. Norman Rosenberg, Law Noir, in LEGAL REELISM: MOVIES AS LEGAL TEXT 281-89 (John Denvir ed., 1996) [hereinafter LEGAL REELISM]. Ironically, given his focus on law, Rosenberg affords no time to Northside's exploration of legal evidence, which is our primary focus.

Telotte and Krutinik both concern themselves with locating Call Northside 777 within traditional film genres, making the case for the film as a "documentary noir," a hybrid of the film noir and the documentary traditions. See J.P. TELOTTE, VOICES IN THE DARK: NARRATIVE PATTERNS IN FILM NOIR 134-35 (1989); FRANK KRUTNIK, In A LONELy STREET: FILM NOIR, GENRE AND MASCULINITY 20208 (1991). They identify the film as part of an impressive cycle of movies produced roughly between 1945 and 1950 that purported to offer realistic and objective accounts of urban crime. Also described as "semi-documentary crime thrillers," this cycle of films includes other Twentieth-Century Fox productions like Hathaway's THE HoUSE ON 92ND STREET (Twentieth-Century Fox 1945) and 13 RUE MADELEINE (Twentieth-Century Fox 1946), and Elia Kazan's BOOMERANG (Twentieth-Century Fox 1947). Other titles in this cycle include Jules Dassin's THE NAKED CITY (Universal Pictures 1948), Anthony Mann's T-MEN (Eagle Lion Films 1948) and BORDER INCIDENT (Metro-Goldwyn-Mayer 1949), Alfred Walker's HE WALKED BY NIGHT (Bryan Foy Productions 1949), Maxwell Shane's CITY ACROSS THE RIVER (Universal-International 1949), George Sherman's THE SLEEPING CITY (Universal-International 1950), and John H. Auer's THE CITY THAT NEVER SLEEPS (Republic 1953).

As an attempt to situate the film historically, grouping Northside this way makes sense. Like the other films, Northside proposed to offer American audiences something different from the Hollywood fare they had been fed on before the war, something as socially charged and informative as the popular newsreel The March of Time, which the American public watched in theaters nationwide during the war. Like these films, March employed a stentorian voice-over, actual footage, and, as Bosley Crowther once remarked, "the reenactment of an event so effective that it simulates reality itself." Bosley Crowther, Imitations Unwanted, N.Y. TIMES, Feb. 22, 1948, at B1, quoted in TELoTTE, supra, at 135. Aesthetically and methodologically, Northside also has much in common with these films. What they share, as Telotte puts it, is their "consistent and calculated slippage from a documentary 'look," their deliberate flirtation with the supposed boundaries between Hollywood fiction and documentary. TELOTTE, supra at 136.

However, the term "documentary noir" presupposes a hard-edged, even cynical, treatment of its subject, which Northside does not offer. The film is too optimistic, too univocal, and too confident about the possibilities for justice to fit comfortably in the category "noir." And although Northside possesses important documentary characteristics, some of which we will discuss later, it participates less in the documentary tradition than these other films, which generally cast unknown performers and paid much less attention than Northside to such elements as dramatic conflict and narrative closure. Northside is at once much more Hollywoodish and, in a sense, more historically accurate than most of these other films. Elia Kazan's Boomerang is perhaps the film with which Northside shares the greatest affinity: Like Northside, Boomerang is closely based on an actual murder case; it mixes elements of classical narrative with documentary techniques; and it concerns itself with questions about witnessing, testimony, and the sufficiency of legal evidence. Although Boomerang was released on video, it was released in a limited press and is not widely available to viewers at present.

17. Beyond the three authors discussed above, see supra note 16 , the area of film scholarship that has produced the most commentary on Northside is noir studies, which generally upholds the film as marking an important contribution to the genre. It is featured, for example, in Silver and Ward's encyclopedia on film noir, where it is described as a "fine example of what might be called 'newspaper noir." SILVER \& WARD, supra note 12, at 49-50. Stuart Kaminsky includes it as one of 121 "key" film noirs in a list he compiled. STUART KAMINSKY, AMERICAN FILM GENRES 274 (1985). Still, most critics afford it only very brief discussion, no doubt because it lacks so many of noir's typical characteristics. See, e.g., NichOLAS CHRISTOPHER, SOMEWHERE N THE NIGHT 15, 44, 52, 91, 
words?

We will argue that Northside can be read as a study in evidence. It is a film that speaks powerfully to the question of what counts as proof and what persuades, both in the courtroom and in our cultural imagination. Northside strongly suggests that legal conceptions of what constitutes good evidence may deviate from more broadly-held ideas of legitimate proof, and that these divergences threaten to lead to injustice. Legal standards of evidence are portrayed as rigid and conservative, too willing to rely on the unreliable and too resistant to novel forms of knowledge.

In this Article, we show in detail how Northside sets up a hierarchy of evidentiary forms. Expert evidence is deemed more trustworthy than eyewitness testimony, but the photograph is portrayed as the best evidence of all, offering proof superior to the expert and lay witness alike. Through this hierarchy, the film not only critiques legal conceptions of evidence, but also suggests that visible, technologically produced proof is the most authoritative and reliable. That is, Northside suggests that the "cure" for the problems of legal proof can be found in science, in the conclusions of experts, and even better, in the objectivity of new technologies. Northside imagines an ideal form of evidence that can provide for narrative closure and moral certainty: The film is in search of proof of innocence, not merely evidence that casts doubt on guilt. In the film, as we shall see, it is a newly discovered photograph that provides this kind of evidence, evidence that rises above the competing narratives of the trial-the witnesses and counter-witnesses and contradictions-evidence that allows no inference but innocence. ${ }^{18}$ Or at least, as we shall argue, the photograph

168, 210 (1997); Ed Gorman, Lee Server \& MaRTin H. GreenberG, THE Big BoOK OF Noir 5, 70 (1998). Other key authors on noir make no mention of Northside at all. Indeed, the seminal text on film noir, RAYMONDE BORDE \& ETIENNE Chaumeton, PANORAMA DU FILM NoIR AMERICAIN, 1941-1953 (1955), characterizes noir in such a way that Northside is excluded by definition: They argue that film noir can be distinguished from other crime films in that it offers an "inside," psychological perspective on criminality. Id. at 1. Northside (as well as other crime "semidocumentaries"), by contrast, focuses on the viewpoint of institutional forces like the police, the FBI, and the newspaper industry. Following this line of thinking about noir, some critics do not even mention Northside in their study of the genre. See, e.g., JAMES NAREMORE, FILM NOIR AND ITS CONTEXTS (1998). Northside's uneasy fit within the typical categories of genre may help to account for its limited critical attention, as the genre is one of Hollywood's most obvious ways of ensuring, as film historian John Ellis phrases it, "that its films are promotable to the whole of the potential audience." JOHN ELLIS, VISIBLE FICTIONS 200 (1982).

18. Note that in its claim that the techniques of science can provide an antidote to the imperfections of the trial process, Northside prefigures current efforts to use DNA evidence to acquit convicted criminals. Like the photographic evidence depicted in Northside, DNA evidence appears to offer the possibility of rising above "mere" narrative and accessing truth directly. In this Article, we shall argue that this is precisely the promise of visual evidence in Northside (and, we shall suggest, of filmic evidence in actual courts as well), but that it is a promise based, in the end, on illusion. We do not, in this Article, take up DNA evidence directly, but Northside, as a story of wrongful conviction, a study in evidence and a critique of law, should be analyzed with DNA-especially its dazzling ability to unravel the stories generated at trials and to turn what seemed to be compelling narratives of guilt into "mere" fictions-in the background. For the dramatic story of the efforts of Barry Scheck and others to use DNA to exonerate the wrongly convicted, see JIM DWYER, PETER NEUFELD \& BARRY SCHECK, ACTUAL INNOCENCE (2000). 
in Northside seems to do so until examined closely.

In fact, in presenting the photograph as the highest form of proof, Northside simplifies and ignores the complications posed by photographic evidence. The film thus invites examination of whether confidence in visual and photographic evidence is, in fact, too easily generated, the picture too easily believed. This question of whether cinematic evidence is dangerously seductive is important, too, for the analysis of films as courtroom evidence. In fact, during the two decades preceding the release of Northside, films had made their way into actual trials, forcing judges to determine whether they were enough like the "real thing"- - or even too much like the "real thing"- to be allowed into evidence. As we shall see, for the most part judges shared the vision set forth in Northside of film as a nearly transparent medium of truth.

However, our unpacking of Northside suggests that both within legal processes and within cinematic depictions, the power of visual evidence necessarily relies on a kind of illusion, a willingness to ignore the mechanisms by which visual evidence is made, shaped, and constructed. In this sense, the courtroom and the cinema may have more in common than might be expected: Both domains operate as theaters of proof in which the power of sight may be both the most effective rhetorical mode of persuasion and an especially fragile basis for conviction. ${ }^{19}$

19. Looking to a popular film for insights about law is not entirely novel. Indeed, in recent years, there has been a groundswell of interest in the relation of law and film. See, e.g., RICHARD K. Sherwin, When Law Goes Pop: The Vanishing Line between law and Popular Culture (2000) [hereinafter SHERWIN, WHEN LAW GOES PoP]; LEGAL REELISM, supra note 16; Carol Clover, Movies Juries, 48 DE PAUL L. REv. 389 (1998); Lawrence Douglas, Film as Witness: Screening Nazi Concentration Camps Before the Nuremberg Tribunal, 105 YALE L.J. 449 (1995); Donald H.J. Hermann, The Law in Cinema: An Emerging Field of Study, 42 N.Y.L. SCH. L. REV. 305, 306 (1998); Orit Kamir, Judgment by Film: Socio-Legal Functions of Rashomon, 12 YALE J.L. \& HUMAN. 39 (2000); Carrie Menkel-Meadow, The Sense and Sensibilities of Lawyers: Lawyering in Literature, Narratives, Film, and Television, and Ethical Choices Regarding Career and Craft, 31 MCGEORGE L. REV. 891 (1996); Norman Rosenberg, Hollywood on Trial: Courts and Films, 1930-1960, 12 LEGAL HIST. REV. 341 (1994); Richard K. Sherwin, Law Frames: Historical Truth and Narrative Necessity in a Criminal Case, 47 STAN. L. REV. 39 (1994) [hereinafter Sherwin, Law Frames]; Rennard Strickland, The Cinematic Lawyer: The Magic Mirror and the Silver Screen, 22 OKLA. CITY U. L. REV. 13 (1997); Symposium, Legal Reelism: The Hollywood Film as Legal Text, 25 LEGAL STUD. F. 199 (1993).

This emergence of "law and film" as a topic of scholarly study emerges, broadly, from the more established "law and literature" movement, which has, in recent years, begun to tum to the analysis of less traditional literary forms. Within the law and literature movement, there have been numerous efforts to typologize; one distinction often made (and often criticized) is between the study of "law in literature" and the study of "law as literature." See, e.g., IAN WARD, LAW AND LITERATURE: POSSIBILITIES AND PERSPECTIVES 3 (1995) (detailing the "familiar distinction between law in literature and law as literature").

While the study of law in literature is, to be sure, extensive, surprisingly little of it has focused on the questions of evidence and proof. There are a few notable exceptions. See, e.g., ALEXANDER WElsh, Strong Representations: NARRATIVE aNd CiRCuMSTaNTIAL EVIDENCE IN ENGLAND (1991); Judy M. Cornett, The Treachery of Perception: Evidence and Experience in Clarissa, $63 \mathrm{U}$. CIN. L. REV. 165 (1994); Special Issue, The Status of Evidence, 108 ProC. MOD. LANG. ASSOC. (1993). This Article explores how Northside represents and critiques legal evidence; in this sense, it emerges from the "law in literature" (or in this instance "law in film") paradigm. 
We thus also use Northside as a jumping-off point for a broader exploration of the reception of filmic evidence, first by examining Northside as a "reenactment," a hybrid form that lies somewhere between drama and documentary, and then, at the end of the Article, by taking a sideways glance at the use of reenactments and other films in actual trials. Reenactments as a form of popular entertainment have grown exponentially in recent years, and they have also begun to receive scholarly attention. ${ }^{20}$ No one, however, has yet explored Northside as reenactment, or linked the film back to the actual Chicago murder case on which it is based. Moreover, none of the recent work on reenactments links reenactments to law and legal processes. It turns out, however, that reenactments and trials (and their outcomes) have a special relation: They are both, at heart, attempts to recapture the past in an authentic and credible fashion. Neither can claim to capture the past directly, nor even to be true in some grand metaphysical sense, but both verdicts and reenactments want to be seen as being true to the past in all of the ways that count.

We thus have two central purposes in this Article. The first is to examine Northside's exploration of various modes of legal evidence, particularly its privileging of photography as the most valuable form of such evidence. The second goal is to offer a meditation on the hybrid status of the reenactment, both by reflecting on Northside's status as a reenactment and by describing the actual use of reenactments and other films in the courtroom during the 1940s. Looking at judges' decisions regarding reenactments during this time period reveals an unmistakable tendency to simplify the complications posed by the use of film as evidence. This tendency resonates not only with Northside's own simplifying strategies but also with those of the documentary and its related subgenres, demonstrating how both cinema and the courtroom depend on visual naïveté in order to make evidence work.

This Article is divided into four Parts. The first Part looks back to the actual Chicago wrongful conviction case on which the film was based. In addition to bringing back to light the intriguing history of a case that formed the basis of a popular Hollywood film, this discussion provides necessary context for our continued attention to Northside as reenactment in Part II. Only by reading the film with attention to the actual case can we show how precisely the film mirrors the case on which it was based-and, importantly, the critical junctures where it does not. The second Part of the Article turns to the film itself. We suggest that the film is best understood as an early exemplar of a reenactment: a retelling of a true story in sufficient detail and with enough fidelity for the audience to understand the film as "fact" instead of, or alongside, "fiction." We then turn to the 
heart of the Article, in which we explore the film's claims and reflections about legal evidence, but with particular attention to those places where the film departs from its source. We argue that the film sets up a hierarchy of evidence, with the eyewitness at the bottom and the photograph on top. We maintain that Northside's depiction of evidence serves both to critique legal conceptions of proof and to buttress the film's own authority as a truthful representation of the actual case. In Part III, we turn to the use of actual films in the courtroom around the time of Northside itself, in order to show some of the interesting parallels between Northside's claims about visual proof and the reception of films in actual courtrooms. Finally, in the Conclusion, we suggest that this double examination of Northside as a study in evidence and the reception of filmic evidence in court suggests an important affinity between the trial and the filmed reenactment: Both attempt to create believable stories of the past, stories not literally true that nonetheless come to be seen as true, stories that even become substitute depictions for what actually occurred.

\section{THE ACtual CASE}

December 9, 1932 was a cold day, even by the standards of Chicago in the wintertime. ${ }^{21}$ It was nearly eleven degrees below zero when, at about 3:00 in the afternoon, two armed men entered Mrs. Vera Walush's speakeasy in Chicago and announced, "This is a stick-up."22 What began as an attempted robbery ended in a murder: The two men shot seven bullet holes into Officer William Lundy and then escaped unharmed in an automobile. ${ }^{23}$ One of the bullets penetrated Lundy's heart and he died immediately; his gun was never fired ${ }^{24}$ Right before Christmas, a twentyfour-year-old Polish immigrant named Joseph Majczek was arrested and charged with the crime, and a few weeks later, a friend of his was arrested as well. At the trial, the two defendants claimed to have alibis for the time of the murder. Though Majczek chose not to testify because he had a police record, witnesses provided him with an alibi, testifying that he had been home at the time of the robbery, helping to carry coal into the house. ${ }^{25}$ Several of the witnesses to the crime admitted that they had not seen the two men clearly enough to make a positive identification. In fact, initially, Vera Walush also claimed she had not gotten a good enough look: "I was so scared that I ran away before I could look at them," she

21. Jack McPhaul \& James McGuire, Here's the Story Behind Slaying of Policeman, CHI. DAILY Times, Nov. 27, 1944, at 3.

22. Id.

23. Policeman Slain As He Grapples with Bandits, CHI. TRIB., Dec. 10, 1932, at 5.

24. Id.

25. Jack McPhaul \& James McGuire, Charge Majczek Victim of Bungling, CHI. DAlLY TIMES, Apr. 2, 1945, at 5. 
said in her initial statement to the police. ${ }^{26}$ The jurors, however, never learned about this earlier statement. ${ }^{27}$ And in the courtroom, Vera Walush dramatically fingered the two men as the culprits, and claimed to be certain about it. ${ }^{28}$

Sure enough, after two hours and forty minutes of deliberation, the jury found the two men guilty. ${ }^{29}$ The jury declined to impose the death penalty and instead sentenced them to ninety-nine years in prison. ${ }^{30}$ The judge indicated subsequently that he believed that the two men were actually innocent and that a second trial would clear them. ${ }^{31} \mathrm{He}$ began to interview the various witnesses himself, conducting what almost amounted to a second trial in his judicial chambers. ${ }^{32}$ He told several people, including one of the witnesses at the trial, that he did not think the trial had been fair, and that he would do whatever it took to get the defendants another trial, even if he had to pay for it himself. ${ }^{33}$ However, for reasons that never became clear, but most likely involved the judge's desire to be re-slated in the upcoming election, he eventually stopped pursuing the case, and died without ever helping Majczek and his co-defendant overturn their convictions. $^{34}$

The defendants appealed, but the Supreme Court of Illinois upheld their convictions, finding, "The testimony of one witness may be sufficient upon the question of identity. Even though denied by the accused, the testimony of one witness may be sufficient to sustain a conviction." 35 Moreover, because Majczek's incompetent attorney (who was subsequently disbarred $)^{36}$ had failed to make the proper motion for a new trial, necessary to preserve the issue for consideration on appeal, the Supreme Court declined to review the question of whether the sum of the evidence offered was sufficient to support a conviction. ${ }^{37}$

While Joseph Majczek pined away in Joliet-a prison built as a Benthamite Panopticon-Majczek's mother toiled assiduously, scrubbing floors in a Chicago office building, utterly convinced of her son's

26. Jack McPhaul \& James McGuire, Postman's Story at Odds with That of "Finger Woman," CHI. DAILY TIMES, Nov. 29, 1944, at 3.

27. Id.

28. Woman Points Out Killers at Slaying Trial, CHI. TRIB., Nov. 9, 1933, at 7.

29. Two Get 99 Years for Police Slaying, CHI. TRIB., Nov. 11, 1933, at 1.

30. Id.

31. McPhaul \& McGuire, supra note 26, at 3.

32. Jack McPhaul \& James McGuire, Trial Witness Insists Identification False, CHI. DAlLY TIMES, Nov. 28, 1944, at 4.

33. Id.

34. See Jack McPhaul \& James McGuire, Judge's Son Joins Fight To Free Joe, CHI. DAILY TimES, Apr. 5, 1945, at 3.

35. People v. Majczek, 195 N.E. 653, 656 (Ill. 1935).

36. Jack McPhaul \& James McGuire, Joe Majczek's Fate up to Board, CHI. SUNDAY TIMES, Apr. 8,1945 , at 10 .

37. Majczek, 195 N.E. at 656 . 
innocence. She saved as much as she could, and on October 11, 1944, she placed a classified ad in the Chicago Daily Times, saying "Five thousand dollars reward for killers of Officer Lundy on December 9, 1932. Call Gro-1758, 12-7 p.m." ${ }^{38}$ A young reporter noticed it, and, thinking it might contain the seeds of a human-interest story, passed it along to her editor.

Two reporters took an interest in the case and investigated thoroughly. One of the early articles describes how, after reading the prisoner's account of the case,

The TIMES man found the case history an eye-opener-if. If it could be accepted as gospel, Joe Majczek was one of the world's hard luck guys... . But the reporter couldn't forget that a man in prison, brooding long nights over the loss of his freedom, often drifts into the realm of fantasy and delusion, and in time comes to believe the figments of his imagination. And Joe had been in prison for 11 years. ${ }^{39}$

Over time, however, the reporters became convinced of Majczek's innocence. Not only did the prisoner pass a polygraph test, ${ }^{40}$ but the reporters found that the police had pressured Vera Walush by threatening her with prosecution for bootlegging, and that she had later told friends that her identification had been false. ${ }^{41}$ They also discovered that Vera Walush had failed to identify Majczek the first two times she saw him in a line-up, and that she had been hiding in a closet for the entire duration of the robbery, affording her little chance even to glimpse the two men she later identified as guilty. ${ }^{42}$ The reporters even tracked down some of the original jurors at the trial, all of whom said that if they had known about the evidence adduced by the newspaper staff, they never would have voted to convict. ${ }^{43}$

In August 1945, Joseph Majczek was pardoned by the governor of Illinois and released from prison. ${ }^{44}$ The Illinois legislature voted to give him $\$ 24,000$ in partial compensation for his ordeal. ${ }^{45}$ His wife had divorced him at his urging and remarried to spare their son the trauma of a

38. Chi. DaIly Times, Oct. 10, 1944, at 30.

39. Jack McPhaul \& James McGuire, Trial Witness Insists Identification False, CHI. DAILY TIMES, Nov. 28, 1944, at 3.

40. Jack McPhaul \& James McGuire, Lie Detector Clears Joe, CHI. DAILY TIMES, Dec. 4, 1944, at 3 .

41. Jack McPhaul \& James McGuire, Swears Joe's Conviction Based on Lie, CHI. DAILY TIMES, Dec. 3, 1944, at 4 .

42. Jack McPhaul \& James McGuire, Frame-Up Seen in Witness' Acts, CHI. DAILY TIMES, Nov. 30,1944 , at 3 .

43. Jack McPhaul \& James McGuire, 4 Jurors Would Acquit Joe Today, CHI. DAILY TimES, Dec. 5,1944 , at 3 .

44. James McGuire \& Jack McPhaul, Joe Majczek Wins Fight for Freedom, CHI. TIMES, Aug. 15, 1945 , at 3 .

45. Green O.K. 's $\$ 24,000$ for Joe Majczek, CHI. SUN, June 29,1947 , $\$ 1$, at 5 . 
father who was a cop-killer. ${ }^{46}$ After his release, Majczek and his wife remarried, and Majczek became a modestly successful insurance salesman ${ }^{47}$ Two years later, Twentieth-Century Fox bought the rights to the story, paying $\$ 1000$ to Majczek and $\$ 2500$ to journalist James McGuire, one of the authors of the Chicago Daily Times articles that led to Majczek's freedom. ${ }^{48}$ (Jack McPhaul, the other author of the series of articles, received no payment. $)^{49}$

\section{CALL NORTHSIDE 777}

\section{A. Northside as Reenactment}

As it opens onto its first scene, Northside promises to offer an explicit recounting of the Majczek story, a promise on which it largely delivers. The film in fact follows the original case to a remarkable degree and in tremendous detail. In order to assure viewers of its fidelity to history, the film begins by appropriating documentary codes and rhetoric. It alerts us (through the opening image of a "shooting script" stamped "urgent") that this is a "true story" whose scenes have all been shot on location in Chicago. ${ }^{50}$ Unusually for its time, Northside was shot almost entirely on location, and partly in the very settings where the actual case had taken place. A stentorian voice-over guides us through the film's first ten minutes, recounting both the history of Chicago after the great fire of 1871 and the facts of the murder case on which the film is based. ${ }^{51}$ With documentary-like style camerawork, including high-grain film, long shots of the city's seedy neighborhoods and buildings, and footage from actual police arrests in Chicago during the 1930s, the clear intention of the film is to appear to reconstruct the crime and the investigation faithfully-both to expose the injustice of Frank Wiecek's conviction and to reveal and

46. Jack McPhaul \& James McGuire, Stork Plays Role in Joe's Defense, CHI. DaIly TIMES, Dec. 2,1944 , at 3 .

47. Joseph Majczek Dies; Wrongfully Convicted in Killing, CHI. SUN TIMES, May 31, 1983.

48. Houston, supra note 13.

49. Id.

50. The film was indeed shot substantially on location, with locations that included a variety of Chicago streets, the 19th precinct, the questioning room in the Chicago Criminal Courts building, and the state penitentiary at Joliet. See Exhibitor's Campaign Sheet, CALL NORTHSIDE 777 (n.d.) (on file with authors); see also Houston, supra note 13. Similarly, Hathaway's The House on 92nd Street begins with an introductory title that tells us that the film was "photographed in the actual places the original incidents occurred."

51. The use of this kind of voice-over provides another way in which Northside departs from film noir. Noir frequently employs voice-overs by characters whom we discover through the film's diegesis to be unreliable, delusional, or simply uninformed. Classic examples of this pattern include Edward Dmytryk's MURDER, MY SWEET (RKO 1944), Billy Wilder's DOUBLE INDEMNITY (Paramount 1944), and Orson Welles's THE LADY FROM SHANGAI (Columbia 1948). An equally powerful, but less wellknown, film noir is Anthony Mann's RAw DEAL (Edward Small Productions 1948), which provides one of the only instances of a female voice-over in the noir canon. 
revel in the possibilities of film as a medium for truth. ${ }^{52}$ As advertisements for the movie proclaimed, "Every word is true." 53

Yet, in what will turn out to be the first of several disruptive shifts in the film, the first ten minutes of documentary soon give way to classical Hollywood narrative. ${ }^{54}$ Northside switches from exterior shots of Chicago that perform as social history to interior shots of the Chicago Times, signaling to the viewer that a more personalized, even if institutionalized, perspective will now take over. And, sure enough, the series of interior shots concludes with James Stewart's face in close-up, a shot meant to accentuate his star status and all the associations of honesty it carried with it. The film thus turns to the identifiable and less-threatening terrain of classical narrative, offering a reprieve for audiences from its own documentary strategies and impulses, "making truth both dramatically effective and comfortably acceptable," according to J.P. Telotte, one of the few film critics who has given Northside scholarly attention. ${ }^{55}$

But Northside does not shift from gritty documentary to classic film narrative simply to appease its audience. By borrowing tropes and visual conventions from two typically distinct genres, the film forces us to recognize the ways in which two supposedly distinct modes of filmmaking, documentary and drama, converge. ${ }^{56}$ Moreover, the blending

52. The House on 92 nd Street also employs footage of the actual investigation on which it was based.

53. Exhibitor's Campaign Sheet, supra note 51.

54. Indeed, the documentary "look" does not fully appear again until the last few minutes of the film-an important point, given that what is sandwiched in between is mainly classical narrative, Hollywood style. At the film's ending, the stentorian voice-over returns, as do the long shots, which provide the sense that the film is pulling away from the personal story of Wiecek and McNeal in order to position itself once again as being interested in larger, social problems-in problems, that is, that make up the content of the documentary.

55. TELOTTE, supra note 16, at 136. Rosenberg reads this transition as the film's move away from a "distanced," critical look at the police to a sympathetic focus on the private individual, who must fight against the injustices caused by institutional forces such as the police. Rosenberg, supra note 16 , at 285 .

56. Of course, even supposedly "pure" documentaries raise similar questions about the ways in which they are constructed and fictional. Telotte writes of the "uncertainty" and "contradiction" that characterize Northside and hybrid films like it in general, but theoretically, these adjectives can describe even the most "truthful" of documentaries, because the genre must always work against and through the fictionalizing tendencies of cinema. See TELOTTE, supra note 16, at 135-37. Media historian Paula Rabinowitz, describes how documentary films "speak about themselves as contradictory texts. Full of self-doubts about their status as organs of truth and reality, the films and their criticism unravel like so much celluloid on the cutting-room floor." PAULA RABINOWITZ, THEY MUST BE REPRESENTED: THE POLITICS OF DOCUMENTARY 23 (1994). Although not exclusively devoted to documentary film, her study offers an especially fascinating look at the genre because of the way it interweaves multiple modes of representation in Depression-Era America (such as the photographs taken by the Farm Security Administration and populist writing) with documentary film per se. See also MichaEl RENOV, THEORIZING DOCUMENTARY 1-14 (1993). In the introduction to the book, Renov provides a useful list of some of the key "fictive elements" that appear in many nonfiction films: the construction of character, the use of poetic language, narration, or musical accompaniment to heighten emotional impact, the creation of suspense, the use of high or low camera angles, close-ups "which trade emotional resonance for spatial integrity," and the use of editing. Id. at 3. Thus, we fully recognize that some of the arguments we make about how reenactments force 
of genres invites questions about narrative form: Exactly how should stories be produced? What kind of stories best capture a viewer's attention, documentaries or dramas? Which are most likely to persuade, those that reproduce the actual as literally as possible, or those that smooth out the rough edges of reality, playing to sentiment and even sensation? The inevitably complex relation among representation, reality, and persuasion plays out within the film first in the relation between McNeal's newspaper stories and Wiecek's "real" circumstances. The same questions recur in the second half of the film, when Northside dramatically shifts its focus from the newspaper industry and how it produces stories to the legal system and how it weighs evidence. Finally, the film as a whole and its relation to the actual Majczek case invite a similar inquiry into the thorny problem of what it means to represent an event faithfully. We will continue to take up these questions throughout this Article.

The first half of Northside looks at how the newspaper industry responds to the Wiecek case, illustrating the newspaper's propensity for sensationalism. Like the actual reporters on whom he was based, the character played by James Stewart, J.P. McNeal, specializes in humaninterest stories. And, as Hollywood drama, Northside aligns itself with the kinds of stories McNeal produces: stories that reduce the plurality of wills, purposes, and loose ends to a unified narrative of a mother's faith, a son's devotion, and innocence revealed. As McNeal types away at his typewriter, we recognize that the stories' implied readership closely resembles the viewers envisioned by the film: an audience desirous of a seemingly objective point of view, adherence to a cause-effect logic, characters who elicit our sympathies, and a progression toward narrative closure-all the elements, in short, that constitute the stuff of classical film narrative. ${ }^{57}$

Indeed, by spotlighting the stereotyped, sensational stories McNeal writes about the Wiecek case, Northside initially takes the production of classical narrative as its underlying subject. Rather than representing the facts of the case, McNeal garners tremendous public interest in Wiecek's case by writing stories with "mass appeal"-what he himself calls "hammering out a sob story." He "plays up" the "mother angle" and the "police corruption angle," for example, even when there is not yet any clear indication that the police acted unprofessionally. ${ }^{58}$

epistemological questions could also be applied to documentaries: Still, what interests us in particular about the reenactment is precisely that it is explicitly fiction though it claims the authority we associate with the representation of the actual.

57. Much critical discussion has been devoted to the subject of classical narrative cinema. The most insightful work on the subject includes the following: DUDLEY ANDREW, CONCEPTS IN FILM THEORY (1984); ElLIS, supra note 17; JAKOB LOTHE, NARRATIVE IN FICTION AND FILM: AN INTRODUCTION (2000); and Laura Mulvey, Visual Pleasure and Narrative Cinema, SCREEN 19 (1979).

58. This rather cynical look at how the newspaper industry functions is surprisingly common in film noir. Other films that offer negative representations of the newspaper or magazine industry 
Importantly, the very "angles" he takes in his stories are those exploited by the film - the faith and devotion of Wiecek's mother, the loyalty of her son, and ultimately the possibility of police corruption - as if McNeal's hunches for what makes good story material predict the filmic content. To reinforce the connection between McNeal's stories and the cinematic narrative, the camera repeatedly zooms in on McNeal's printed words as they appear in his typewriter. As we see in close-up titles such as "Wiecek places faith in mother" and "Mother slaves to save son," we recognize that these titles perform as textual summaries of what we have just witnessed on film.

At the same time, we also know that these titles, and the stories that follow them, do not accurately represent all that we have seen. We are thus encouraged to believe that we have a privileged viewpoint, privileged not only as compared to that of the film's imaginary readers of the newspaper but also as compared to the viewpoint of the actual readers of the case in $1932 .{ }^{59}$ This double viewpoint- the sense that we are being manipulated by the film as if we were newspaper readers, and a simultaneous belief that we are receiving a more "truthful" version of the case-harks back to the film's opening image of a typed page from a manuscript stating that Northside is a "true story" and also a "shooting script." Documentary and fiction at once, the pages from Northside's script are indeed like those of the newspaper's: Both tell truth and fiction, even if the film encourages us to see it as somehow coming closer to the real than its textual counterpart.

While McNeal's early stories may attract readers, they cannot directly win Wiecek his freedom because they traffic mainly in narrative devices, not in evidence. "In the world Northside sketches, fictionalizing itself becomes the true antagonist, the impulse to veil or disguise reality, the culprit against which the film's documentary strategy is mobilized," Telotte argues. ${ }^{60}$ In order to exonerate Wiecek, McNeal must abandon his sensational narratives for facts, or more accurately, for an alternative means of shaping his narratives. Consequently, the film reaches an important turning point when McNeal finally loses his skepticism about Wiecek's innocence and declares that "I'm willing to dig, get the facts." At this halfway point in the film, McNeal becomes an investigator as well as a storyteller, getting affidavits, digging through police files, unearthing

include John Farrow's The Big Clock (Paramount 1948) and Fritz Lang's The Blue GardeniA (Alex Gottlieb Productions 1953), BEYond A REAsonable DoubT (Bert Friedlob Productions 1956), and WHILE THE CITY SLEEPS (Bert Friedlob Productions 1956).

59. A miniature version of this position occurs frequently in film noir, in scenes where the camera provides a close-up shot of the front page of a newspaper. As we read the newspaper's factual account of the storyline that we are following in the film, we realize that we know much more than the newspaper account provides, both in terms of the facts of the case and the psychological motivations of the characters involved. For interesting examples of this technique, see Vincent Sherman's NoRA PRENTISS (Wamer Brothers 1947), and Arthur Lubin's IMPACT (United Artists 1949).

60. TELOTTE, supra note 16 , at 149. 
photographs. Soon he begins to learn about what constitutes evidenceevidence, that is, according to the law. And in so doing, he transforms into a very different kind of reporter.

Indeed, the law serves as a kind of corrective institution to the newspaper industry here. ${ }^{61}$ Though represented as inflexible and severe, its expectations for proof demand a deeper level of investigation and commitment from McNeal. ${ }^{62}$ More importantly, they demand the same things from the film itself. By setting up the law's criteria for conclusive evidence as the catalyst for its own climax, Northside redefines its own methods and objectives midway through the film. The film moves slightly away from classical narrative-away from emotional scenarios focused mainly on Wiecek's mother and her belief in her son-toward a more scientific, "objective" examination of the Wiecek case. Indeed, Northside becomes an exhibition of and meditation on three different kinds of evidence, each of which we will discuss in detail: eyewitness testimony, expert testimony in the form of a lie detector test, and a photograph. The result of this journey through evidence, as we will see in Part III, is a clear hierarchy that privileges image over narrative, or more accurately, upholds the photographic image as offering an ideal type of narrative because it offers a seemingly ideal type of evidence.

While the first half of Northside focuses on McNeal and the investigative articles he produces, the second half thus presents an extensive meditation on how the legal system decides what counts as admissible evidence. Like other hybrid crime films of the period, particularly The House on 92nd Street and T-Men, Northside spotlights modern techniques of detection, and in so doing, as Frank Krutnik explains in his book on masculinity and film noir, presents detection "not as a matter of intuitive action but as one of organizational machinery." 63 As we show in the next Part, this concentration on "organizational machinery" bolsters Northside's own documentary claims by suggesting that photography is the most effective of all such machineries. ${ }^{64}$

61. This positioning of the law as a corrective force against fiction is, of course, conveniently naïve. Following in a long tradition of scholarship on the subject, Richard K. Sherwin has recently made clear the extent to which law depends on storytelling. See SHERwI, WHEN LAw GOES POP, supra note 19, at 41-71. For classic accounts of the importance of narrative and storytelling to the trial process, see W. LANCE BENNETT \& MARTHA S. FELDMAN, RECONSTRUCTING REALITY IN THE COURTROOM 62 (1981); and Nancy Pennington \& Reid Hastie, A Cognitive Theory of Juror Decision Making: The Story Model, 13 CARDOZO L. REV. 519 (1991) (arguing that juries turn evidence into narrative).

62. In this sense, our interpretation of Northside differs radically from Rosenberg's. While he sees the film as consistently critical of law, we read Northside as offering a more ambivalent representation. On the one hand, the film does portray the legal institution as both narrowminded and inflexible. On the other hand, the law tempers and corrects McNeal's initial penchant for sensationalizing and drawing assumptions without conclusive evidence. Rosenberg, supra note 16 , at 283.

63. KRUTNIK, supra note 16 , at 203.

64. Other films that spotlight visual machineries include Anthony Mann's $T-M e n$, which presents 
This celebration of photography as a machinery of truth, creates a tension in Northside between the claims of narrative and those of the image. The film's climax rests on the authority of the photograph: Narrative seems to give way in Northside to the silence of a single, indisputable image. As silent witness, the photograph apparently stands opposed to narrative, its evidentiary power seemingly not in need of literary or even verbal accompaniment. Indeed, after the photograph offers the proof Wiecek needs to be set free, we never see the reporter McNeal write a story again. By following this trajectory, the film ultimately resists confronting its own fictional pressures and motivations. For all its exploration of how narrative and evidence work, Northside resists exploring the ways in which its documentary impulses are contradicted by its fictional impulses, by its effort to tell a story that, like McNeal's, will possess mass appeal. Just as importantly, it ignores the fact that all photographs, once they are enlisted for evidence, also get enlisted-to however small or great degree-for fiction.

Northside is part tearjerker, part documentary. It is often characterized as a film noir, but in many important ways Northside is far from noir, whose narratives generally defy logic, closure, and optimism, embracing ambiguity and cynicism as their modus operandi. ${ }^{65}$ We suggest that the best single classification of Northside is as a "reenactment." 66 The

a dazzling and elaborate scene in which the police construct a life-size image of a criminal suspect on a projection screen as various witnesses provide their physical description of him. Henry Hathaway's The House on 92nd Street spotlights the various surveillance techniques, including hidden cameras and two-way mirrors, employed by the FBI.

65. Noirs, of course, range in both degrees of cynicism and narrative experimentation. Interestingly, those films that provide the most complex narrative structures (using such techniques as convoluted time frames, voice-over narrators who withhold or misrepresent information, and flashbacks) often figure as the most cynical in subject matter and tone, since the corruption and decay they spotlight is exacerbated for the viewer by the confusion she feels in following the storyline. Examples of such films include Anatole Litvak's SORRY, WRONG NUMBER (Hall Wallis 1948), Jacques Tourneur's OUT OF THE PAST (RKO 1947), and Orson Welles's The Lady from Shangai.

66. Based on an actual murder case, Elia Kazan's Boomerang also falls within our classification of "reenactment." Indeed, the parallels between Kazan's film and Northside are striking: Both begin with voice-overs that recount the details of the murder; both include documentary-style footage that details police work following the murder, such as the rounding up of suspects, examination of eyewitnesses, and search for clues; both indict eyewitness testimony as unreliable and inaccurate. Boomerang also combines the visual style and strategies of documentary and film noir. Like Northside, it continually forces its viewers to shift their vantage point as it moves back and forth between the conventions of classical narrative, noir lighting, and unusual camera angles to a realistic documentary style. As in Northside, this combination is designed to complicate the film's own claims to truth. Boomerang repeatedly admits that its understanding and knowledge of the crime are limited-indeed, like Northside, it chooses as its historical basis a case that was never solved.

Boomerang was based on the aftermath of a murder in Bridgeport, Connecticut in 1924, in which a much-loved local priest was shot to death. There was no apparent motive for his murder. A poor vagabond who matched the murderer's description was soon arrested. Numerous witnesses identified him, ballistics experts matched his gun to the bullet used in the killing, and the suspect even confessed to the crime. It appeared to be, as the prosecutor later told the court, "a well-nigh perfect case, affording but very little difficulty in the matter of successful prosecution." Homer S. Cummings, The State vs. Harold Israel, 15 J. AM. INST. CRIM. L. 7 CRIMINOLOGY 406, 414 (1925). But when district attorney Homer S. Cummings (who would later become Franklin Delano Roosevelt's Attorney 
reenactment as a generic form has, until recently, received little scholarly attention, perhaps partly because it is sometimes seen as low-brow, and partly because it is hard to categorize, belonging comfortably neither to the realm of documentary nor to the domain of fiction. However, academics and cultural commentators have begun to turn their attention to the form. This may be the result of the recent explosion of film and television reenactments of scandals-from Jon-Benet Ramsey to Amy Fisher-and of more serious quasi-historical films like JFK or Mississippi Burning. ${ }^{67}$

General), arrived to prosecute the case, he announced that he would instead ask for a nolle prosequi. Despite the seemingly overwhelming evidence against the suspect, the prosecutor had found after meticulous investigation that the evidence simply did not hold up. The well-nigh perfect case turned out to be as leaky as a sieve. Charges were dropped, and the case was never solved. For the prosecutor's full statement to the court describing the evidence and its flaws, see id. On the case more generally, see Anthony Abbott, A Perfect Case, 6 THE RoTARIAN 14 (1945). Like Northside, Boomerang follows the real incident on which it is based in tremendous detail, though like Northside, it also departs from the true story in one important particular, designed to provide the viewer with a kind of certainty and closure that the real world story lacked. Instead of leaving the case wholly unsolved, as it was in real life, the film version provides the viewer with an alternative murderer and a theory of the crime, though the details are left murky.

Most importantly for our purposes here, Boomerang shares Northside's interest in the epistemological complexities of reenactments; indeed, Boomerang's interest is arguably even more self-conscious and self-reflexive than Northside's. The final third of Boomerang focuses on the trial of the suspect, a trial in which the state's attorney proves the man's innocence through various reenactments of the events leading up to the murder. Designed only to prove the innocence of the suspect rather than to identify the actual murderer, these reenactments show that it would have been physically impossible for the suspect to have committed the murder and that the testimony of the witnesses was false. The film presents these reenactments in two ways: in the film's present, with the prosecutor acting out events before the jury in the courtroom, and in the film's past, through flashbacks that show the attorney and his group of assistants reenacting the details of the crime in the actual places where they happened. These reenactments perform two functions: (1) They link film viewers with jury members as they complicate for both groups the details of the crime and, more importantly, (2) They draw attention to the film's own status as a reenactment, alerting us to the fact that, like these individual reenactments, the film can only say what did not happen; it cannot offer complete truth. As Telotte remarks in his useful discussion of the film, "It's as if the film itself were on trial, its method for revealing truth called into question." TELOTTE, supra note 16, at 142.

In some ways, the challenge presented by Northside and Boomerang resembles, though not nearly with the same degree of self-consciousness, recent films represented by the "New Documentary" movement. Characterized by self-reflexivity and interactive techniques, the New Documentary marks an attempt to overcome any simple dichotomy between truth and fiction. As film theorist Linda Williams observes in her essay on the movement, these films suggest that there is no "a priori, selfevident truth to be "captured" by the camera, but that there are multifaceted, receding horizons of "truth" that can be constructed within a multivocal (multigazing) form." Linda Williams, The Ethics of Intervention: Dennis O'Rourke's The Good Woman of Bangkok, in COLLECTING VISIBLE EVIDENCE 176, 183 (Jane M. Gaines \& Michael Renov eds., 1999). The foremost figure in this movement is Errol Morris, whose widely acclaimed film THE THIN BLUE LINE (American Playhouse 1988) gamered so much critical attention precisely because it questioned its own participation in the representation of truth. Other directors whose work is representative of this movement are Dennis $O^{\prime}$ Rourke and feminist filmmaker Trinh T. Minh-ha. For more information on the movement, see generally COLLECTING VISIBLE EVIDENCE, supra. See also Linda Williams, Mirrors Without Memories: Truth, History, and the New Documentary, FILM QUARTERLY 9 (Spring 1993); and Sherwin, Law Frames, supra note 19.

67. See, e.g., John CORNer, The ART Of Record (1994); DEREK PAGET, No Other WAy to Tell IT: Dramadoc/Docudrama ON TElevision (1998); Alan Rosenthal, Writing DOCUDRAMA: DRAMATIZING REALITY FOR FILM AND TV (1995); WHY DOCUDRAMA: FACT-FICTION ON FILM AND TV (Alan Rosenthal ed., 1999) [hereinafter WHY DOCUDRAMA]. Much of the recent 
In a thoughtful discussion of the genre, Steve Lipkin describes how the reenactment (or, as he calls it, the docudrama) functions:

Even as docudrama departs from documentary proper, the two modes retain a certain semiotic similarity.... The documentary image functions as an index; comparable imagery in docudrama remains primarily iconic; however, docudrama asks if, under its terms, the two signs might not be all that different. The films' often high degree of resemblance to [the] actual . . creat[es] what amount to indexical icons, signs with direct, strongly motivated resemblances to their actual referents. We are offered argument by analogy, the analogies (images) often appearing to be the most literal kind. ${ }^{68}$

In his book on television docudrama in America and Britain, media scholar Derek Paget also emphasizes that the reenactment is "an inherently indexical form," necessarily pointing "beyond the realm of fiction to a realm of non-fiction that is always already-lived." ${ }^{\circ 9} \mathrm{He}$ writes,

The drama-documentary seeks to overlay the Stanislavskian emotional equivalence of "As If" with a documentary-indexical "See This!". The relation to reality claimed in the solely dramatic "as if" through equivalence and parallel is asserted in dramatic documentary mode through the repetitions of reconstruction/reenactment (these words/actions, in this place-with a gesture back to "that time"). Where one set of actions is in parallel to the real, the other is an attempt to superimpose, to fit with a template, an acted "reality" on film on to a previous, unfilmed one. ${ }^{70}$

Understanding Northside as a reenactment emphasizes its dual allegiances: both to representing the true story on which it is based and to telling a powerful and dramatic tale. These theorists of the reenactment offer two useful concepts for examining Northside. First, Lipkin's concept of the indexical icon lets us see how the film aims simultaneously to offer both index and icon: a literal telling of a particular truth and something broader, more eternal and allegorical. Divided in purpose, Northside necessarily demands a divided response from viewers, who must not forget either that it is a Hollywood drama or that it is true. Moreover,

scholarship uses the term "docudrama" or "drama-documentary" for that which we term "reenactment." We prefer the term "reenactment," both because it resonates with the filmed reenactments used in trials that we shall discuss in the final part of the Article, and because "docudrama" can suggest a much broader (and for our purposes too broad) range of material. The term "docudrama" can refer not only to dramatic renderings of actual occurrences (or, what we term "reenactments"), but also to dramas inspired only loosely by actual events or drawn from a collection of actual instances, or even to the presentation of wholly fictional material in a documentary-like fashion. For a much broader cultural analysis of the prevalence and significance of copies, doubles, twins, and reenactments, see HILlEL SCHWARTZ, THE CULTURE OF THE COPY (1996).

68. Steve Lipkin, Defining Docudrama, in WHY DOCUDRAMA, supra note 67, at 371-72.

69. PAGET, supra note 67 , at $136-37$

70. Id. 
Paget's idea that the reenactment operates like a template, fitting over the real while still allowing departure from the actual so long as the basic "shape" is maintained, invites us to explore the correspondence between the film and the material on which it is based, to see when the template fits and when it fails.

Thinking about Northside as a reenactment thus focuses attention both on its fidelity to the actual case on which it is based and on its status as a fictional representation. It highlights how the film sets itself up as a Hollywood drama that can nonetheless be trusted as an account of what "really" happened. ${ }^{71}$ Reenactments straddle the actual and the fictional, and they necessarily raise questions about belief, persuasion and proof. What makes an audience believe that the story they watch is essentially true? How much dramatic license can a reenactment take before losing the authority that comes from an alliance with the actual? In what follows we will look in detail at how Northside treats questions of evidence and proof.

\section{B. The Question of Evidence in Northside}

The single most remarkable feature of Northside is the fact that it takes evidence itself as its subject. Indeed, the film continuously circles around questions of proof, evidence, and facts. In the newspaper reporter's first encounter with the convict, he tells Wiecek that he has read the record and it does not "whitewash you, the way I see it." Wiecek responds, "But you only read what convicted me. All the true facts didn't come out." As McNeal reveals his skepticism, Wiecek asks him, "You don't believe me, do you?" The reporter is unabashed. "Listen, I talked to your mother. She's a very fine old woman. She believes you, I need proof."

Later in the film, McNeal is forced to tell Wiecek's mother that they are going to have to call off the hearing before the Pardon Board because they lack sufficient evidence. She is both outraged and dismissive: "Evidence? They got no evidence when they sent my Frank to prison for ninety-nine years. I got no evidence when I scrub floors every night, go without supper, walk to work, so I save a nickel for Frank. Evidence. What is this evidence?"

By the end of the film, McNeal has had a conversion, and it is his turn to criticize the Pardon Board for its narrow conception of proof:

Strictly from a reporter's point, you understand, I've assembled what I feel is a very solid case. It consists of such debatable items as a lie detector test. Now I realize that you're unable to accept that. You want evidence. But sometimes the weight of evidence, just because it's in the record, is heavy enough to crush the truth.

71. Lipkin emphasizes that docudramas "warrant": "The viewer is invited to accept the argument that re-creation warrants, that what we see might have "really' happened in 'much this way."' Lipkin, supra note 68 , at 372 . 
"We'll discuss the shortcomings of the judicial system some other time, Mr. McNeal," a member of the board of pardons replies curtly.

We can see in these three brief moments a complex relation between faith, evidence, and proof. The mother requires no evidence at all. She believes in her son's innocence because she believes in her son. The most incriminating evidence would not dislodge her belief, for it is based on faith rather than inference from evidence. However, when she places the ad offering reward money in exchange for evidence of the real killer, she recognizes that the rest of the world cannot share her faith, and that her only hope of overturning her son's conviction is to locate new evidence, either of her son's innocence or of someone else's guilt. Thus she works for years, saving the money that she hopes may buy the proof she needs: the money that may spur someone to take an interest, to come forward with the evidence that will persuade others of what she already knows.

By contrast, McNeal, the reporter, starts out doubtful about Wiecek's innocence. $\mathrm{He}$ is on assignment, and he is initially dubious that there is anything even worth investigating in this now stale murder case. He has to be badgered by his editor into pursuing the matter at all. At first, McNeal figures that because he has been tried and convicted, Wiecek is almost certainly guilty; the legal judgment of conviction is itself adequate proof of guilt to satisfy the reporter. After their exchange in prison, McNeal is intrigued but still skeptical, just like the actual reporters on whom he was based. Over the course of the film, however, McNeal comes to be entirely persuaded that Wiecek has been the victim of a miscarriage of justice. He comes to share Wiecek's mother's faith in her son-but his is a faith that emerges from his reading of the evidence, not from an unshakeable belief in the good character of a particular man. ${ }^{72}$ Moreover, he has become a critic of the legal system's too-narrow conception of evidence. There is, he believes, proof that can persuade and reveal the truth, yet that will nonetheless be rejected as legal evidence. As he gains faith in Wiecek's innocence, he loses faith in law and legal processes. He fears that evidence, in the legal sense, can crush the truth. And, as the film progresses, it almost does.

\section{The Eyewitness}

In the film (as in Joe Majczek's actual criminal trial), the primary legal

72. The film's depiction of the necessary quantum of proof to persuade is explicitly gendered. It is the female characters-not only Wiecek's mother, but also McNeal's wife-who are prepared to believe without explicit proof, while for McNeal, merely wanting to believe is not enough to persuade him. In a living-room exchange, McNeal's wife asks him, "Why don't you let go? You want him to be innocent, you want him to be free." "Well, maybe you're right. Maybe I do want him to be free, but that doesn't make me believe he's innocent," counters McNeal. "You want to believe. That's enough," his wife insists. This, of course, reflects a classically gendered opposition between faith and proof, or, more typically, emotion and reason. Thanks are due to Fred Blumberg for pointing out to us the significance of gender in Northside. 
evidence against the defendant was the identification provided by an eyewitness to the shooting, the owner of the speakeasy in which the policeman was killed. And it turns out that this eyewitness was lying. The film never explains why the owner was lying. McNeal seeks out the witness and eventually finds her. She is nervous and uncooperative, but she neither recants nor offers any explanation for her original incriminating testimony-nor does she even acknowledge that she failed to tell the truth. Implicitly, the film suggests that she may have been coerced by the police. After all, she was engaged in bootlegging and thus may have been pressured under threat of prosecution to identify Wiecek. In fact, in the actual case, there was strong evidence suggesting that the speakeasy owner was indeed pressured; she subsequently even admitted to a friend that her identification was "improper and false." 73 When her friend prodded her conscience, asking her how she could help convict an innocent man, Vera Walush's response was, "Well, what the hell did you expect me to do? I had to go along with the police, didn't I?"74 In the film, however, the speakeasy owner's motive for identifying Majczek/Wiecek remains murky, as does her fear and unwillingness to explain herself eleven years later.

By failing to provide a specific explanation for this particular eyewitness's perjury, the film implies that eyewitness testimony in general ought to be viewed with suspicion. The report of one's own eyes may be unreliable and false-and the legal approach to evidence, the film suggests, does not adequately take into account the limits of eyewitnesses' vision. Eyewitnesses may be corruptible or just plain mistaken. Human testimony can be marred by police pressure, the fallibility of memory, fear, the lapse of time, or worst of all, deliberate falsehood. ${ }^{75}$ As posed by Northside, the unreliability of eyewitnesses is less a problem of inevitable subjectivity than it is a problem of no mechanism for measurement, no way of knowing who-or what-is worthy of credit. Eyewitness testimony is presented as too mediated and too subjective to be trustworthy, especially when that which has been seen is not shared by others, is not part of a larger vision, a corroborated story. The film thus suggests that while eyewitness testimony is sufficient to support a conviction in the legal sense, it ought not to be deemed sufficient to support conviction in the sense of belief.

Concerns about the accuracy and fidelity of eyewitnesses are nothing

73. McPhaul \& McGuire, supra note 41 , at 4 .

74. Id.

75. A significant literature has emerged on the limits of eyewitness testimony, focusing in particular on the frequency with which eyewitness identification can be mistaken. See, e.g., BRIAN L. Cutler \& Steven Penrod, Mistaken IDENTIFiCATION: The Eyewitness, Psychology and the LAW (1995); ElIZABETH LOFTUS, EYEWITNESS TESTIMONY (1996); Samuel Gross, Loss of Innocence: Eyewitness Identification and Proof of Guilt, J. LEG. ST. 395 (1987); Gary L. Wells \& Eric P. Seelau, Eyewitness Identification, 1 PSYCH. PUB. POL'Y \& L. 765 (1995). 
new. Literary critic Alexander Welsh, for example, has argued that as early as the eighteenth century, novelists, scientists, and judges all came to prefer the evidence of "things not seen"76 to that of human testimony, viewing inferences from uncontested circumstances as stronger evidence than an eyewitness account. ${ }^{77}$ Even though this concern with the fallibility of the eyewitness is longstanding, both crime semi-documentaries and classic film noir evince a particular concern, even obsession, with the limits of the eyewitness, all of the ways in which such evidence can be corrupted or merely mistaken. ${ }^{78}$ These film genres thus reflect a growing recognition that human memory is frail and suggestible, that line-ups and photospreads might be tainted by conscious or unconscious signaling on the part of the authorities, and that the passage of time has a negative effect on memory. Northside is thus one of a spate of films dealing with crime during the 1940s and 1950s that share a marked concern with the unreliability of human testimony. One of the most notable examples of film noir's treatment of this theme, for example, is Alfred Hitchcock's The Wrong Man, ${ }^{79}$ in which an innocent man (Henry Fonda) is almost convicted of armed robbery because four separate witnesses make a "positive identification" of him as the culprit. As in Northside, all of those who could testify to his innocence are either missing or dead. ${ }^{80}$

Boomerang, a 1947 film directed by Elia Kazan, also emphasizes the unreliability of eyewitnesses. In this film, a beloved priest is murdered one evening on a street corner, and multiple eyewitnesses subsequently identify a suspect, John Waldron, as the killer. Waldron is arrested and brought to trial in what appears to be an open-and-shut case. But after carefully attempting to verify the eyewitnesses' claims and staging reenactments of the crime itself, the prosecutor becomes convinced that the suspect did not, in fact, commit the murder, and asks the judge to drop the charges. Like Northside, Boomerang was based on a true story, and like Northside, the film emphasizes the precariousness of justice. Just as

76. WELSH, supra note 19, at 7 (citing Hebrews 11:1 ("Now faith is the substance of things hoped for, the evidence of things not seen.").

77. See generally id. at $2-42$.

78. In addition to the films discussed in our Article, other titles include Robert Siodmak's PHANTOM LADY (Universal 1944), in which a cabdriver, bartender, and singer are all paid off by a wealthy murderer not to corroborate the alibi of an innocent man, who is then tried, convicted, and sentenced to die in eighteen days; Robert Siodmak's THE FILE ON THELMA JORDAN (Hall Wallis 1950), in which the prosecuting attorney perjures himself on the stand by lying about evidence so as to defend the woman he is supposedly prosecuting; Jack Amold's THE TATTERED DRESS (UniversalInternational 1957), which depicts a notoriously amoral lawyer who is charged by a juror with bribery-only for the film to later reveal that the juror had been lying all along; and Otto Preminger's ANATOMY OF A MURDER (Columbia 1959), in which several eyewitnesses lie on the stand to protect themselves from a man they fear.

79. THE WRONG MAN (Wamer Brothers 1956).

80. This is also a recurring motif in Alfred Hitchcock's films, including THE THIRTY-NINE STEPS (Michael Balcon, Gaumont 1935), VERTIGo (Paramount 1958), and NORTH BY NORTHWEST (MetroGoldwyn-Mayer 1959). 
Wiecek would never have been freed but for the enterprising efforts of McNeal, Waldron would surely have been convicted and locked away if it hadn't been for a persevering district attorney who investigated the case with a diligence hardly typical and who refused to cave in to political pressure to prosecute.

In Sidney Lumet's Twelve Angry Men ${ }^{81}$ a juror (also played by Henry Fonda) persuades eleven other jurors to change their votes because he consistently demonstrates how easily an eyewitness can be deceived. He points to the case of one woman who swears she saw through a window a son murder his father, even though she was too nearsighted to view anything clearly at such a distance; and the case of an elderly man who stated that he opened his apartment door when he heard a crash and saw the son fleeing the scene of the crime, even though, as Fonda proves, his handicapped leg would have prevented him from walking fast enough to open the door in time..$^{82}$ In both cases, the eyewitnesses do not seem to be acting out of malice; they are simply convinced that what they remember is true. Perhaps the most notorious filmic exposé of eyewitness unreliability, Billy Wilder's Witness for the Prosecution, ${ }^{83}$ focuses on the wife of an alleged murderer (Marlene Dietrich) who appears in court as a hostile witness against her husband, precisely so that she can then create a false identity and appearance, meet with the defending attorney, and produce letters that will discredit her own damaging testimony against her husband.

Whereas crime semi-documentaries of this time period tend to represent eyewitnesses as unreliable so as to promote the need for more scientific means of establishing evidence, classic film noir tends to use the figure of the unreliable eyewitness as a means of illustrating the unreliability of all discourse in modern culture. "Through a thematic focus on our discourse," J.P. Telotte writes, "these films [film noir] show how fundamentally our communications, even the movies themselves, carry a certain estranging force, one that renders all discourse precarious and every effort at human communication a risky wager against misunderstanding and alienation." 84 Telotte includes semi-documentaries like Northside with such unmistakable noirs as Edward Dmytryk's Murder, My Sweet and Anatole Litvak's Sorry, Wrong Number as support for this observation. But Telotte fails to recognize that semi-documentaries and classic film noir possess widely different reasons for their focus on narrative unreliability. Semidocumentaries are much more invested in the unreliability of eyewitnesses

81. TWELVE ANGRy MEN (United Artists 1957).

82. Given the fact that only one year earlier, Hitchcock had cast Henry Fonda as a man whose life is nearly ruined by false eyewitness testimony in The Wrong Man, it seems highly probable that Lumet was capitalizing on this association by casting Fonda as the juror most skeptical of such testimony.

83. WITNESS FOR THE PROSECUTION (United Artists 1957).

84. TELOTTE, supra note 16 , at 30 . 
as a social problem that needs to be corrected through more efficient means of detection, while classic film noir is, as a genre, much more interested in the lying or mistaken witness as an existential problem that, by its very nature, cannot be corrected.

While Northside clearly takes a much more "documentary" approach to crime than a classic film noir allows, its spotlight on the unreliability of eyewitness testimony is the element that brings the film closest to the style, mood, and overall effect of classic film noir. After locating its viewers in generally well-lit, "safe" settings such as McNeal's newspaper office or the domesticated apartment he shares with his wife, Northside dramatically plunges us into the noir landscape when McNeal goes in search of Wanda Skutnik in order to persuade her to recant her identification. During these fifteen minutes, the camerawork in Northside changes dramatically. Most of the scenes are done in night-for-night shooting; characters' faces, including Stewart's, are shown only half-lit; and physical space becomes much more restricted and, consequently, the individual frames of the film become much tighter.

Although this noir-dominated series of scenes only lasts for fifteen minutes in a film that spans nearly two hours, it resonates throughout the remainder of the film, functioning like Northside's black hole. ${ }^{85}$ And, indeed, it is the film's black hole, inhabited by a woman who refuses to change her testimony for no given reason, and who will not provide McNeal with any information whatsoever. Despite the film's confidence in its own role in the establishment of truth and justice, for these fifteen minutes Northside is pulled into a vortex that it must fight its way out of. Providing that vortex is film noir's work; restoring viewers and the film itself to the possibility of truth and effective social action is the work of both classical film narrative and documentary. At this point, Northside leaves noir safely behind and suggests to its viewers the practical need for more certain, more scientific evidence. ${ }^{86}$ Like other films focused on crime, Northside points to the aspirational possibility for alternatives to the eyewitness, alternatives that seemed, in the 1940s, close on the horizon. One of those alternatives, as we shall see next, was the lie detector test.

But before we turn to this alternative form of evidence, it is important to note that Northside's "noirish" treatment of Wanda Skutnik-its focus on

85. This kind of mini-incorporation of noir elements also occurs in Frank Capra's IT's A WONDERFUL LIFE (RKO 1946), during the scenes in which George Bailey must revisit his hometown as if he were dead, and in Alfred Hitchcock's SHADOW OF A DOUBT (Universal 1942), where a scene shot in a seedy, darkened bar seems almost like a violation of the rest of the film, which is brightly lit and occurs mostly in domestic spaces.

86. Ironically, these "noirish" scenes, which are much more stylized than those of the rest of the film, could also be read as the most realistic in that they call attention to the extreme poverty and physical degradation that pervaded parts of Chicago. As Rosenberg points out, they "highlight the sociocultural gulf between McNeal's and Wanda's worlds." Rosenberg, supra note 19, at 288. 
her silence, obstinacy, and perverse sense of complacency in letting a man remain in jail long after, it seems, she could be threatened by the policemeans that we never find out in the film if or why Skutnik was forced to lie on the stand. Nor does the film resolve an even bigger mystery: Who actually killed the policeman that day in the speakeasy? The film leaves that mystery (which was also never resolved in the actual case) alone, and in doing so, admits that there are parts of the Wiecek case that cannot be reenacted. The focus on Skutnik thus not only exposes the limitations of eyewitness testimony but also makes clear that we may never entirely know what "really" happened. In its quest to recover the past in an authentic and credible fashion, Northside has to abandon its interest in Skutnik at this point, leaving behind the thematic strain that most interests film noir-the impossibility of ever recapturing the past—for the dubious promises of the reenactment. ${ }^{87}$

\section{The Lie Detector Test}

After Northside demonstrates so much skepticism about the reliability of human testimony, the film turns to a machine as the next-and bettermeans of providing evidence.$^{88}$ As we will demonstrate, however, the film's representation of the lie detector is marked by a certain degree of ambiguity. If Northside seems confident in its stance on the unreliability of eyewitness testimony, its position on the evidential value of the lie detector is much more complicated - a fact that in some ways reflects the larger history of the lie detector in courtroom procedures.

When McNeal asks Frank Wiecek if he would be willing to take a lie detector test, the prisoner quickly agrees: "Mr. McNeal, for eleven years I've been waiting for a chance to get at that box." McNeal emphasizes that it's a dangerous bargain for Wiecek: "You know what you're up against? If it turns out bad, you're cooked. If it turns out good, it's only Leonarde Keeler's professional opinion. It doesn't count legally." But Wiecek is

87. Indeed, the elusiveness and mystery of one's past, or the past of others, haunts the majority of film noir protagonists, including Jeff Bailey in Jacques Tourneur's Out of the Past, Rip Murdock in John Cromwell's DEAD RECKONING (Columbia 1947), George Steele in Irving Reis's CraCK-UP (1946), and Vincent Parry in Delmar Dave's DARK PASSAGE (Warner Brothers 1948).

88. Another film noir of this time period that makes interesting use of the lie detector is Joseph Lewis's THE BIG COMBo (Security-Thedora 1955), also starring Richard Conte. In this film, Conte plays Mr. Brown, a powerful mobster who continually outsmarts the detective, Leonard Diamond, on his trail. No method employed by Diamond-harassment, surveillance, and an 18,000 dollar policeforce budget-successfully stops Brown's criminal activity until Diamond deploys a lie detector test. During this test, Diamond utters a series of words/names to which Brown must automatically respond with another word/name. While Brown remains calm, even cavalier, throughout most of this test, he falters when he hears the name of a man whom he has managed to silence with money, a man who could provide evidence of a murder Brown committed several years ago. Diamond triumphantly says, "You can't lie with your blood pressure!" Thus, we know that the detective has finally found the one method that, in however minor a way, has located Brown's vulnerability. Though this scene is extremely brief, its revelation of Brown's vulnerability establishes a chain of discoveries that ultimately ends with Diamond killing Brown as the latter resists arrest. 
determined, even eager, hoping that the test will persuade others of his innocence. Back in his prison cell, he is warned of the dangers of the test by another convict: "Listen kid, take it from me. Keep away from Keeler and that lie detector.... Why, I had the cops, the state's attorney, even my own lawyer believing me. Then they talked me into going against that box." "What happened?" queried Wiecek. "What do you mean what happened. I'm doing life, ain't I?" the prisoner replied. This brief exchange, implying that the convict's attempt to fool authorities was exposed by the lie detector, suggests that the machine can triumph over even the most calculated performances. Given our supposition by this point that Wiecek is telling the truth when he says that he is innocent, it would seem that the scene is constructed so as to reassure viewers that the test will work in Wiecek's favor.

Still, the scene is peculiarly unsettling, for while it appears to be validating the lie detector as a conveyor of truth and justice, it also draws our attention to the machine's potentially devastating and detached power. The fact that the prisoner describes his experience as "going against that box," for example, emphasizes both the seeming absence of a human operator behind the machine as well as the prisoner's ignorance about how the machine works. Cinematographically, this scene is also infused with tension and a vague sense of foreboding, framed as it is in noir's low-key lighting and with the camera lingering in close-up on Frank's anxious face as he meditates on the prisoner's comments. We imagine what Frank must be feeling: that this test could somehow work against him as it did for the other prisoner; that once the machine renders its verdict, his words could be forever discounted; that in one brief session, his fate could be irrevocably decided.

The basic premise behind the polygraph test is that human beings have physical responses to the stress of lying that are beyond their will and control. The body can reveal the mind, and inner mental states can be rendered visible, exposed by the machine. ${ }^{89}$ The lie detector continuously measures the prisoner's blood pressure as he or she answers numerous questions, both mundane and significant. The completed test results in a graphic representation of the changes in blood pressure - rendering visible someone's invisible internal states through the intervention of technology. But this seemingly simple procedure belies a whole range of complex questions. How ought one to read the transcript of the body? What do the fluctuations in blood pressure mean? How does one translate the reflection of physical processes to the underlying mental state $?^{90}$ Eliciting meaning

89. See the discussion of the lie detector test in Ronald R. ThOMAS, DETECTIVE Fiction AND THE RISE OF FORENSIC SCIENCE 21-39 (2000). Thomas traces the rudimentary beginnings of the polygraph in the late nineteenth century, arguing that its development answered the cultural need for, and anxiety over, making the human body readable.

90. Modern polygraphers have developed an elaborate set of approaches-including asking 
from a polygraph thus requires interpreters with specialized knowledge. Yet, neither in the 1940s nor at present is there any regulated set of credentials required for one to claim to be a polygraph expert, no specifically mandated course of study nor any testing procedures to assure competence.

Other issues have also made the use of lie detectors controversial. While the test itself is straightforward enough, it rests on highly problematic assumptions. The basic premise behind it is quite simple: Telling lies creates stress or anxiety, and this stress or anxiety is echoed physiologically and recorded on the polygraph. Untruths leave traces. ${ }^{91}$ The problem with this reasoning is that physiological responses that suggest stress or anxiety may be generated by a number of factors, only one of which is lying. Perhaps someone is made nervous merely by taking the test. Perhaps the anxiety generated by the accusation is itself sufficient to generate a physiological response that mimics that typically generated by a liar. Perhaps some liars feel no anxiety and register no change in physiological response even when they fail to tell the truth. The physiological response measured by the polygraph can only record that some response is taking place; it cannot determine the cause of that response or its meaning without interpretation.

On several occasions, the film reminds its viewers that the lie detector is not legitimate legal evidence-and indeed, even up to the present courts have been quite reluctant to authorize lie detector tests as legal proof..$^{92}$ In

suspects unusual and embarrassing "control" questions to gauge their physical responses or instructing them to lie when asked a particular question or questions - to attempt to create test methods that can provide secure knowledge. For a thorough discussion of the strengths and weaknesses of the polygraph today, compare David C. Raskins, Charles R. Honts \& John C. Kirchner, The Scientific Status of Research on Polygraph Techniques: The Case for Polygraph Tests, in MODERN SCIENTIFIC EVIDENCE 565 (David Faigman et al. eds., 1997), with William G. Iacono \& David T. Lykken, The Scientific Status of Research on Polygraph Techniques: The Case Against Polygraph Tests, in MODERN SCIENTIFIC EVIDENCE, supra, at 582.

91. The premises behind the polygraph test, in this sense, are strikingly similar to the premises behind police uses of photography in the nineteenth and early twentieth centuries. Both in Britain and America, the police took photographs of criminals and criminal suspects not only for identification purposes but because it was still widely assumed in both these countries, thanks to the extraordinary popularity of physiognomy as a mode of social science, that the physical features of a person revealed his or her internal traits. Thus, if one studied the details of a photograph closely, one could "read" a person's guilt or innocence in his or her face. In both photography and the lie detector, then, the body betrays its owner. For contemporaneous examples of this belief in photography's revelatory powers, see thomas Byrnes, Professional Criminals of America (1886); and Cesare lombroso, CRIMINAL MAN (1911). For the seminal discussion of this phenomenon, see Alan Sekula, The Body and the Archive, in THE CONTEST OF MEANING: CRITICAL HISTORIES OF PHOTOGRAPHY 343, 348-52 (Richard Bolton ed., 1990).

92. See, e.g., United States v. Scheffer, 523 U.S. 303 (1998). In the last few years, however, there has been a slight softening toward the polygraph in some jurisdictions, with some courts holding that polygraphs ought to be analyzed on a case-by-case basis rather than presumed inadmissible. See, e.g., United States v. Cordoba, 104 F.3d 1997 (9th Cir. 1997); United States v. Posado, 47 F.3d 428 (5th Cir. 1995); United States v. Pulido, 69 F.3d 192 (7th Cir. 1995); United States v. Glabreth, 908 F. Supp. 877 (D.N.M. 1995); United States v. Crumby, 895 F. Supp. 1355 (D. Ariz. 1995). 
fact, Frye v. United States, ${ }^{93}$ a 1923 case that remains influential as a standard for approaching expert evidence even today, ${ }^{94}$ examined the admissibility of an early lie detector test. The judge determined that the lie detector test was not yet sufficiently reliable to be used as legal evidence:

Just when a scientific principle or discovery crosses the line between the experimental and demonstrable stages is difficult to define. Somewhere in this twilight zone the evidential force of the principle must be recognized, and while courts will go a long way in admitting expert testimony deduced from a well-recognized scientific principle or discovery, the thing from which the deduction is made must be sufficiently established to have gained general acceptance in the particular field in which it belongs. We think that the systolic blood pressure deception test has not yet gained such standing. ${ }^{95}$

In 1948, when Northside was released, courts typically based their exclusion of lie detectors on a variety of arguments: The experiments were still uncertain, the details of interpretation too murky, and the general reliability of the test insufficiently established. On extremely rare occasions, individual judges did permit such evidence. In one 1938 case, for example, a judge allowed a polygraph into evidence, reasoning thus:

For hundreds of years our courts have deemed the examination and cross-examination of witnesses in open court to be the best method so far devised for the ascertainment of the truth .... It seems to me that this pathometer and the technique by which it is used indicate a new and more scientific approach to the ascertainment of truth in legal investigations. ${ }^{96}$

But this case was atypical, an outlier criticized and dismissed by other judges. ${ }^{97}$ More generally, courts and legal commentators acknowledged that if the lie detector were perfected, it would be a useful tool, but they steadfastly asserted that its time had not yet arrived.$^{98}$ However, throughout the last half-century, courts have been noticeably more stringent in applying this general acceptance standard to the polygraph

93. 293 F. 1013 (D.C. Cir. 1923).

94. In Daubert v. Merrell Dow Pharms., 509 U.S. 579 (1993), the Supreme Court ruled that Frye was not incorporated into the Federal Rules of Evidence. Nonetheless, Frye's test of "general acceptance" remains one of the factors to which judges can look in determining the admissibility of expert evidence, and a number of state courts have chosen to continue to use Frye as their standard for admissibility even post-Daubert. See generally Heather G. Hamilton, The Movement from Frye to Daubert: Where Do the States Stand, 38 JURIMETRICS J. 201 (1998).

95. Frye, 293 F. at 1014.

96. People v. Kenny, 3 N.Y.S.2d 348, 351 (1938).

97. See, e.g., People v. Forte, 4 N.Y.S.2d 913, 916 (1938) (rejecting Kenny's claim that there is sufficient scientific basis for admitting the polygraph into evidence).

98. See, e.g., 2 JOHN HENRY WIGMORE, A TREATISE ON THE SYSTEM OF EVIDENCE $§ 875$ (2d ed. 1923) (declaring that "[i]f there is ever devised a psychological test for the valuation of witnesses, the law will run to meet it," but also admonishing that "[ $t]$ here must first be proof of general scientific recognition that [the test is] valid and feasible"). 
than to numerous other forms of evidence. ${ }^{99}$

Hence, the history of the lie detector's evidentiary status is fraught with complications. The film never goes into these complications, other than to refer to the detector's general exclusion from the courtroom. Since these difficulties with the polygraph are largely absent from the film, the legal system's refusal to accept the polygraph as legitimate evidence seems somewhat odd in Northside, even perverse. Just as the film offers no compelling explanation for the speakeasy owner's refusal to tell the truth (and thereby seems to be an indictment of eyewitness testimony in general), the film provides no explanation for the legal system's reluctance to embrace the lie detector test. As represented in the film, the lie detector is entirely reliable, so its unreliability cannot serve as an explanation for its exclusion from trials. In fact, it is the polygraph that persuades McNeal: It is precisely at this point in the film that the reporter's skepticism is transformed into full-fledged conviction, his wavering belief in Wiecek's innocence now a matter of faith. The film invites its viewers to ask how the courtroom's exclusion of such technologies of truth can be justified.

Implicitly, the suggestion is that the lie detector is too threatening-it provides a technology for truth-detection more effective and more efficient than the legal system's reliance on the jury can ever be. It must be kept out precisely because it threatens to replace the trial process altogether, substituting trial by jury for trial by machine. It is the lie detector's potential as pure technology, therefore, that makes it a problematic form of evidence - for the judges, attorneys, and arguably for the film viewers themselves. For while the film represents the lie detector as reliable and accurate, and the legal system as antiquated and myopic in rejecting it as evidence, Northside's representation of the lie detector is nevertheless constructed in such a way as to mystify its functions and epistemological assumptions. This mystification effectively distances viewers from the very machine they are apparently being encouraged to admire, instilling in them a mistrust of its scientific complexity, and therefore, its inaccessibility.

Nowhere is this more evident than in the elaborate, eight-minute scene in which Wiecek takes the test, a scene that demonstrates a peculiar remoteness from the instrument it spotlights. Interestingly, the scene begins in medias res. As a close-up shows us the machine's intricate wiring and gauges, we can hear the voice of someone who sounds like a highly knowledgeable person explaining to McNeal how the machine works. The voice is actually that of Leonarde Keeler, an inventor and advocate of the lie detector, who plays himself on-screen. In fact, it was Keeler himself who had administered Majczek's actual lie detector test,

99. For the continued contemporary debate over the reliability of the polygraph, see the competing perspectives offered in MODERN SCIENTIFIC EVIDENCE, supra note 90. 
concluding both in the actual case and on the screen that the test strongly suggested that the man who had spent more than a decade in prison was telling the truth when he denied any involvement in the crime for which he was convicted. Keeler's appearance in the film thus helps to invest the machine with particular authority, while simultaneously lending the film an even greater documentary aura through this bit of verisimilitude. ${ }^{100}$ Keeler's undoubted expertise also allows the film to skirt around the obvious issue of interpretation and the human mistakes that can potentially come with it. By having Keeler administer the test, the viewers are apparently assured that the reading will be fair and accurate, that the polygraphist brings both integrity and knowledge to the examination. If Wiecek is the author of the text, in that it is produced by his body, its interpretation is authorized by Keeler, whose expert judgment cannot be questioned.

At the same time, however, Keeler's presence in the film ultimately reinforces the film's tendency to mystify the functions of the lie detector. This is evident in several ways, including the fact that, as noted earlier, we only hear part of his explanation to McNeal about how the lie detector operates because the scene begins in media res. Moreover, the mise-enscene repeatedly draws our visual attention to the machine rather than to Keeler, with individual shots framed to place a fragmented figure of Keeler in the background (with only his lower torso visible) while the machine itself looms large in the foreground. The relationship between sound and image is also striking in this sequence of shots, since Keeler's voice is both monotone and jargon-filled; his explanation to McNeal refers to such scientific concepts as "the electrical conductivity of the skin" and "the systolic measurements of the heart." His voice does not attract our interest: What does attract our interest is the spectacle of the machine itself.

In making the workings of the lie detector so visible to viewers, then, the film manages both to enlighten and to mystify us about the machine. We hear Keeler's explanation to McNeal, we hear him ask questions of Wiecek and we hear Wiecek answer them, we watch the machine produce its graph as the two men talk, but we cannot understand how the machine is interpreting the exchange. We observe carefully, aided by the camera's frequent close-ups, but this privileged entry into the production site of the lie detector tells us very little about the machine itself. Nor do Keeler's explanatory comments provide much guidance.

As Keeler administers the test, McNeal, his boss, and the prison warden

100. Some critics of dramadocs and reenactments have singled out for particular criticism the use of small, seemingly genuine details (such as an actor's replication of a real person's mannerisms or the participation of an actual participant) to give the film the semblance of authenticity: "Falseness of gesture and falseness of appearance drive authenticity from docudramas. This is why those who admire these forms of dramatic life find the most trivial touches of verisimilitude so entrancing." Jerry Kuehl, Lies About Real People, in WHY DOCUDRAMA, supra note 67, at 119, 122. 
all watch from behind a window that allows them to see but prevents them from hearing the questions or answers, and the viewers assume this vantage point for a brief period of time as well. This spectatorial foregrounding dramatizes the cinematic dimensions to the scene, which, by placing such stress on instruments and instrumentality, invites a comparison between the lie detector and those of the camera. ${ }^{101}$ Like the lie detector, the camera provides its own recording of Wiecek's physical responses as he answers the questions, focusing on the heaving of his chest, the inadvertent moving of his fingers, the sighs he emits as he answers, and the sweat on his face and hands. Yet, while only Keeler can understand the graphics produced on the white sheet of paper, viewers can read Wiecek's emotional response simply by watching carefully. While the lie detector needs an intermediary to interpret its signs, film does not.

To some degree, the film thus spotlights the lie detector so as to undermine its technology as inferior to its own-inferior, that is, because it is too sophisticated, too scientific, too inaccessible, and, finally, too visible. One could argue, in other words, that the decision to show viewers the scene of the lie detector's production serves the ulterior purpose of masking the film's own site of production. As a wide range of critics have discussed, classical narrative film depends on the invisibility of its mechanisms; its success, in other words, hinges on its own transparencyon the illusion of effortlessness with which it seems to give us its recreated world. ${ }^{102}$ By visualizing the mechanisms of the lie detector test, in all their complex and mystifying glory, Northside simultaneously maintains its own status as a transparent medium onto a "real" world-one that needs no intermediary, no agent.

These observations become especially interesting in light of cultural historian of science Bruno Latour's arguments about how science gets made and disseminated. According to Latour, scientific findings are generated through the use of instruments that create visual displays of various sorts, graphs, charts, gauges, and so on, or what Latour terms "inscription devices." 103 Latour argues that scientific truths are made persuasive precisely through a reliance on these inscription devices: They make it appear as if the viewer, whether fellow scientist or layperson, sees

101. Another fascinating example of a film that spotlights the workings of the lie detector so as to draw attention to its own epistemological status is the much more recent movie, THE POLYGRAPH (Cinea 1996). The opening scene of the film begins with a lie detector test in operation. At the end of the test, the polygraphist informs the suspect that the "results were inconclusive"-a phrase that is repeated several times. As the film progresses, we leam that while the suspect is not guilty of the murder, his intense hatred of the victim and his past behavior toward her complicate his innocence. This revelation is not straightforwardly given in the film's narrative; rather, it comes through a series of intricate visual clues. Hence, the inherent properties and functions of the film's camera perform the same role as the lie detector, rendering the "results" of a close investigation of the protagonist "inconclusive."

102. See, e.g., DAVID A. COOK, A History OF NARRATIVE Film, (2d ed. 1990).

103. BRUNO LATOUR, SCIENCE IN ACTION 68 (1987) 
the results for herself, while the scientific author "behaves as if he or she were [just] the mouthpiece of what is inscribed on the window of the instrument." 104 The viewer's confrontation with the instruments that produce these inscriptions-gauges, meters, physiographs, and all the other instruments of the modern laboratory-is, according to Latour, an "audio-visual spectacle" that generates "conviction." That is to say, visual inscriptions and verbal commentary are far more persuasive in tandem than either would be alone. ${ }^{105}$ But this seeming attempt to make science accessible turns out to mystify its processes even further, since very few people can actually make sense of the inscriptions they are viewing, or even the verbal explanations that accompany them.

Although the lie detector test does not figure into Latour's discussion, its representation in Northside certainly provides an excellent example of the type of inscriptions he analyzes. Viewers see in close-up the graph the lie detector produces, but we have no comprehension of what it means, nor do we fully understand the explanatory words offered by Keeler. Our technological and scientific ignorance is precisely why, the film implies, we need an alternative form of evidence - one that everybody can make sense of and understand, or at least believe that they can. And, hence, the film makes a climactic shift to the final form of evidence it explores: the photograph.

When the film elevates photography as the most accessible and therefore most valuable form of legal evidence, its own self-promotion is thus cemented, as we shall see next. Photography becomes Northside's means of selling its own supposedly simple and simplifying technology. Like classical narrative film, photography also depends on the invisibility of its site of production; it presents itself as natural transcript, ready and waiting to be read and interpreted without need of expert assistance or explanation. And, unlike the lie detector test, which can record only present history as it charts the body's immediate responses to questions in the here-and-now, photography's supposed capturing of the past also means that Northside has finally arrived at the form of evidence that, like itself, aspires to reenactment.

\section{The Photograph}

In the last quarter of the film, Northside explores a third kind of

104. Id. at 71 .

105. Id. Much of Latour's study focuses on the role of the "black box," which, according to him, is a device whose accurate functioning can be taken for granted, a device believed to "work" so that the user need only be concerned with what is put into the box and what is taken out, rather than what goes on inside it. See id. at 2-3, 131-32. According to Latour, to challenge seemingly established science, one inevitably begins to open these black boxes and peer inside. See id. at 29 . Although he does not discuss it specifically, the lie detector, as it is presented in the film, functions as a perfect example of the "black box," while legal decisions questioning the machine's authority present an example of how the "black box" can be re-opened and contested. 
evidence that lacks the defects of the first two, a kind that is portrayed as both reliable and legally legitimate. The photograph is the film's "solution" to the evidentiary conundrum. Unlike the lie detector, the photograph is permitted within legal processes. Unlike an eyewitness, the photograph is trustworthy. The existence of the photograph thus provides the critical evidence that guarantees that Frank Wiecek will go free, the evidence that can force the pardon board to recognize and rectify the grave injustice of Wiecek's conviction for murder. ${ }^{106}$

As photographic historian John Tagg has argued, assumptions about photographic veracity have little to do with the "natural" qualities of the photograph. ${ }^{107}$ Rather, they have been produced and sustained by discursive systems aimed at advancing the authority of certain institutions or forces - such as the media, the penal system, the law, and more specifically, the documentary movement that began in the 1920s. "That a photograph can come to stand as evidence, for example, rests not on a natural or existential fact, but on a social, semiotic process," claims Tagg.

But in Northside, the photograph's evidentiary status is also hardwon. ${ }^{108}$ The first mention of a photograph occurs late in the film, when McNeal explains to his employers and the Chicago Times attorney that he has unearthed a photo from the files of the Times's former rival, and now defunct, newspaper, The Herald Examiner. The photograph depicts a handcuffed Wiecek walking into the police station; in the background is the owner of the speakeasy, Wanda Skutnik, who testified that she saw Wiecek for the first time since the murder when she identified him in a police line-up on December 23. The photograph offers proof that Skutnik was lying, McNeal believes, because he assumes that the picture was taken before the time of the lineup. McNeal is thrilled with his discovery, certain that he has found the critical piece of evidence that will cement Wiecek's claim of innocence.

The attorney dismisses some of McNeal's evidence as inadequate, telling him, "Look here McNeal, I'm an attorney. I know what it is to go up in front of the pardon board. They go on facts." McNeal answers,

106. In this way, Northside provides a similar view of photography to that found in other noir documentaries. Henry Hathaway's The House on 92nd Street and Anthony Mann's He Walked by Night, for example, represent photographically based technologies such as surveillance cameras as invincible, modern forms of detection. In this sense, noir documentaries differ radically from other films noir, which tend to treat photography with much more skepticism. In films ranging from Steve Sekely's THE SCAR (Bryan Foy Productions 1948) to Edward Dmytryk's Murder, My Sweet, the photograph is presented as a highly unreliable piece of evidence. In direct contrast to the strategy of Northside, these types of film noir focus on the misleading nature of photographic images as a means of drawing attention to their own visual unreliability. For other examples of this pattern, see Fritz Lang's Beyond a Reasonable Doubt and Edwin L. Marin's NOCTURNE (RKO 1946).

107. JoHN TAgG, THE BURden OF REPRESENTATION: EsSAYS ON PHOTOGRAPHIES AND HISTORIES 7 (1988).

108. Rosenberg makes the important point that $\mathrm{McNeal}$ demonstrates unequivocal faith in technology while the attorneys in the film are at first quite dubious about the photograph's evidentiary status. See Rosenberg, supra note 16, at 286. 
"Facts, okay, I'll give you something better than facts. I'll give you a picture. ${ }^{109}$ He presents the photograph to the attorney, who takes a quick glance at it, looks to see if anything is written on the back, and hands it back to McNeal, explaining that the photo is useless without a datewithout some kind of self-positioning device that could verify its exact moment in history and thus legitimize its documentary status. ${ }^{110}$ Deflated, $\mathrm{McNeal}$ folds the picture and puts it away in his vest pocket.

In this particular scene, Hathaway's pedestrian camerawork, consisting entirely of medium shots, underscores the photo's status as object rather than symbolic image. ${ }^{111}$ Seen through the eyes of an attorney whose tough, dismissive attitude is intended to influence our response, the photograph does not compel. As viewers of a film with documentary impulses, we may wish to side with McNeal, but we necessarily wind up on the side of the attorney, realizing that without a date, the photo cannot fulfill its documentary role. Until it is linked to a particular moment in time, this photograph means nothing.

The photograph then disappears from the film's plot until the day that the pardon board is due to convene to consider Wiecek's fate. Even though McNeal is absolutely certain of Wiecek's innocence, he is resigned to defeat before the pardon board, for he lacks the sort of proof that counts legally. But then, riding in a taxi, he happens upon a headline on the front page of a newspaper describing a "police enlargement process." 112 The

109. This is precisely the stand that the film ends up taking: Pictures are better than facts, or, more precisely, pictures are the best possible way to prove contested facts.

110. This is also in direct contrast with many noir films' treatment of photography, which tend to use elaborate close-up shots and montages to draw our attention to the physical and symbolic properties. Emphasis on the importance of the date and context recalls Barthes's observations about the function of the photographic caption, which, according to him, guides our vision, even to the extent that "sometimes . . . the text produces (invents) an entirely new signified which is retroactively projected into the image." ROLAND BARTHES, IMAGE-MUSIC-TEXT 27 (Stephen Heath trans., 1977).

111. This dismissive treatment of the photograph contrasts sharply with most representations of photography in classic film noirs. In Robert Siodmak's The File on Thelma Jordan, for example, a district attorney jeopardizes his professional career by falling in love with and helping a murder suspect, Thelma Jordan, whom he believes to be innocent. In a dramatic moment that utilizes a zoom lens and a series of increasing close-ups, the lawyer discovers a photo of Jordan as a former prostitute in the police files and realizes for the first time that the woman he thought he knew is not what she seems. The photograph fills the entire screen, its evidentiary status in effect displacing for both the betrayed attorney and the film viewers a former impression of Jordan —one carefully constructed by the film's cinematography-as a respectable, naîve, and sincere young woman. Paradoxically, then, the police photograph, magnified by Siodmak's camera, offers us a new image of Jordan that possesses far more potency than any previously offered by the film. Watching a film noir, viewers may be seduced by the seeming potency of the photographic image, forgetting about dates, context, and general reliability, but within the perimeter of a quasi-documentary, we are forced to adopt a much more critical stance.

112. To our knowledge, no new enlarging processes had been invented around the time of the film that would have made news headlines. Although photographs can, in fact, be enlarged by $1000 \%$ as the film suggests, the resulting image would almost certainly have been much too grainy for any details to appear clearly. Thus, the film's representation of this technique is quite exaggerated. A relevant discussion may be found in MORRIS GURRIE, THE COMPLETE BOOK OF ENLARGING 19-21 (1949), which was published only one year after Northside was released. 
previously useless photograph now has the potential to assume vital importance, as McNeal hurries down to a police photo lab and begs the technician to enlarge it as quickly as possible. He hopes that the process will reveal the date of a newspaper held by a newspaper boy in the far left corner of the photo, which would determine the date of the photo's origin and thus possibly offer conclusive evidence that Wanda Skutnik was lying. Wiecek's fate thus comes to rest not on the photo itself, but upon the use of a technology that may allow the photograph to "speak." Note, too, the charmingly self-referential twist here: Not only does McNeal find the key to proving Wiecek's innocence by reading a newspaper headline, but within the photograph itself it is a newspaper that may provide the reporter with the evidence he needs to persuade the parole board.

After making the request of the technician, McNeal travels to Springfield, the state capitol, to plead with the pardon board to wait for the enlarged photograph over the AP wire as it is sent from Chicago's police headquarters. In the film's most dramatic scene, six members of the pardon board-along with the film's actual viewers-wait in a state of suspense for the enlarged image to appear. Hathaway sets the scene in a photo lab, the scientific look of the police laboratory lending an authoritative aura to the process. The board members, not up-to-date on the latest procedures for enlarging photographs, listen intently to McNeal's explanation of what the enlargement process can do - that it can magnify an area of a photograph to many times the original size and that the quality of the resultant image will depend on such variables as the "condition of the dup. negative" and the "density of the print." McNeal also tells the board that he's been "praying, too."

As we gaze into the solution bath, the image slowly starts to appear. The film's camera zooms in on the image as it develops, mirroring the enlargement process itself. The cinematic close-up and the enlargement process thus combine to make visible what had previously been left invisible, enacting Walter Benjamin's observation that " $[t]$ he enlargement of a snapshot does not simply render more precise what in any case was visible, though unclear: it reveals entirely new structural formations of the subject." 113 Through this dazzling and extended scene of development, the photograph is transformed from worthless to indispensable: Locating it temporally transforms it into the most reliable of witnesses. As Benjamin explains, the enlargement process has not simply made the image "more precise." The photograph's original subject-Wanda Skutnik and Frank Wiecek entering the police station-is now recast, and the photograph now has a new subject: time itself, verifiable and irrefutable history. The film's enlargement of the photograph, in other words, functions as a kind of reenactment, allowing for a revisiting and reinterpretation of the site of

113. WALTER BENJAMIN, The Work of Art in the Age of Mechanical Reproduction, in ILLUMINATIONS 217, 236 (Hannah Arendt ed., 1968). 
the original image. No longer is the photo just an image of an inscrutable instant. Now it can be placed within a narrative context. Like a single frame pulled from a film, it is one moment captured, but it is now a moment with a clear before and after. ${ }^{114}$

Once the critical date is revealed, everyone-McNeal, the parole board, and the film viewer-knows that Frank Wiecek will go free. No one doubts the authority of the photograph. Even the attorney opposing the prisoner's pardon is silenced by the evidence of the photograph. Moreover, the photograph is portrayed as the exclusive form of evidence that can cross between the various arenas of proof. It is valid both within legal processes and outside of them. In the film, then, the eyewitness is authoritative in the legal setting, but unreliable; the lie detector is authoritative outside the courtroom but irrelevant within it. Only the photograph is capable of commanding authority across domains, equally trustworthy in the theater of the courtroom and in the theaters of the 1940s presenting Northside. It is effective, it would seem, precisely because it lacks the totalizing power of the polygraph-it does not threaten to displace legal process altogether, but only to check it by tempering human judgment with mechanical objectivity. The photograph links together legal proof with lay conceptions of evidence; in both realms, it can be deemed persuasive, legitimate, even dispositive. The photograph not only saves Frank Wiecek, but it redeems legal proof as well, by showing that in the end, legal evidence can suffice to bring the truth to light. ${ }^{115}$

Moreover, this climactic scene, in which the enlarged photograph becomes visible before our eyes (note, here, that the film's audience and the film's characters all view the newly legible photograph together), serves a critical purpose within the film. By presenting the photograph as utterly authoritative, this scene warrants that we can believe what we see. In this sense, the photograph is a stand-in for the film itself. The authority of the mechanically produced visual image is maintained in a double sense: The truth of the photograph affirms the truth of the film as a whole.

114. Looking at a film still, for Roland Barthes, takes place at a divide-at a point where the image, or our perception of the image, undergoes a transformation. Liberated from the narrative impulse of the film, the still nevertheless retains the illusion of movement. Barthes calls this "the possibility of configuration," the "armature of a permutational unfolding." BARTHES, supra note 110, at 77 .

115. But note that while the photograph assures that Frank Wiecek will receive justice, it certainly does not completely exculpate the legal system. The existence of the photograph, that McNeal was able to locate it, that he serendipitously discovered in the cab that it might be possible to have it sufficiently enlarged, and that he was able to find someone who could enlarge it quickly enough in order to reveal the crucial date on the newspaper, are all portrayed as contingent facts, lucky breaks. The photograph might never have been found; or McNeal might never have realized its significance. Without it, Frank Wiecek might well have remained in prison. So Wiecek's release from prison does not turn Northside into a "justice will win out" morality tale; rather, we continue to see how fragile and accidental the rendering of justice can be. Still, the fact that the parole board does respond to the photograph softens the film's critique of law: Legal processes are not viewed as inherently corrupt, but merely rigid. 
Just as the members of the parole board can believe in the authority of the enlarged photograph, the members of the audience can believe in the authority of Northside's retelling of a true crime tale. According to the film, both the photograph and the film itself can be trusted.

Whatever Northside wishes us to believe, however, neither documentary films nor photographs are inherently trustworthy. In fact, Northside's conflation of documentary film and authoritative photograph is an interesting one, in part because the very device that affirms the film's realism turns out to be pure fiction: In the actual Majczek case, there was no photographic evidence, no visual image that helped to secure the actual defendant's release. Rather, in the actual case, though the evidence was compelling, it was murkier and more circumstantial-hardly the stuff out of which film climaxes are made. The film's representation of the photograph as an authoritative means for truthtelling thus turns in on itself ironically, revealing the fabrication of both film and photograph alike. The Majczek case received a great deal of media attention-in addition to the Chicago Daily Times's nearly daily reports, the case got attention from the national press and magazines like Time and Newsweek. ${ }^{116}$ Many of Northside's viewers thus certainly had some previous knowledge of the facts of the case itself, and may even have recognized the irony of the fictionalized climax.

This use of a "fictional" photograph necessarily challenges the film's own claim to be something other than "fiction," suggesting that in the end, drama or narrative impact outweighs any concern for verisimilitude. (And why not?-it is a Hollywood film, after all.) For those viewers who had closely followed the actual Majczek case, those who eagerly read the actual articles in the Chicago Daily Times, this use of a photograph is a kind of a nod and a wink, a gesture to say "Okay, we admit it. Reality isn't quite dramatic enough for film even when reality is at its most dramatic." Genre makes demands that reality cannot live up to.

This takes us back, once again to the question of certainty. ${ }^{117}$ The film seeks to offer a form of proof-both to the parole board and to the viewers - that would eliminate all doubt about Wiecek's innocence. In so doing, the film carries its viewers from doubt to assurance as the narrative progresses: from the mother's faith, to the reporter's polygraph-inspired conviction, to the eventual knowledge that Wiecek is in fact innocent beyond a shadow of a doubt. The photograph turns the mother's faith and McNeal's justified belief into certain knowledge. And yet, ironically, this certainty is built atop a fiction.

It is interesting, however, to recognize how narrowly Northside circumscribes its turn to fiction. We can imagine, for a moment, some of

116. See, e.g., National Affairs: Illinois, TIME, Aug. 27, 1945, at 23.

117. For discussion of the relation between faith and certainty in the film, see supra Section II.B. 
the other ways that the film could have provided dispositive proof of Wiecek's innocence. Most obviously, McNeal's digging might have uncovered the actual perpetrator, necessarily exculpating Wiecek. Alternatively, McNeal might have located another eyewitness to the murder-someone who saw it all, and who could therefore confirm that Wiecek was the wrong guy. Or Wanda Skutnik might have recanted her original testimony, admitting that she had indeed perjured herself out of fear that the police would have arrested her for bootlegging had she failed to identify Wiecek as the guilty man. This list could, of course, go on. Had the film offered any of these forms of proof of Wiecek's innocence, it would have been manufacturing evidence that did not exist in the actual case, just as it did with the photograph. (In point of fact, in the actual case, Majczek's release marked the first time in the state of Illinois that a convicted man was pardoned even without an alternate suspect for the crime.)

But although there was no photograph in the actual Majczek case, the photograph manufactured by the film did not itself manufacture evidence absent from the actual case. The photograph showed Skutnik and Wiecek together outside the courthouse the day before Skutnik's identification of Wiecek. The photograph proved, therefore, that when Skutnik said under oath that she had not seen Wiecek at any time between the day of the murder and the day she identified him in the police station, she was lying. The substance of what was suggested by the photograph was, in fact, suggested by the evidence in the actual case as well. In the actual case, the reporters found Majczek's original arrest slip, and it was dated one day prior to Walush's identification. ${ }^{118}$ Why didn't Walush see Majczek for purposes of identification the very day of the arrest? The one-day delay suggested the plausibility of - though obviously did not prove-Majczek's claim that Walush saw him several times and had to be pressured by the police into making identifying him.

So the photograph did not offer proof that differed in substance from evidence in the actual case, but only evidence that differed in representational form. Instead of merely having Majczek's say-so, corroborated by slight circumstantial evidence, to suggest that Skutnik was lying, the photograph established the same thing in starker, less contestable form. The fiction of the photograph, then, is merely a fiction of form: The contents of the photograph are consistent with what happened in the actual case, but no photograph ever emerged to operate as a "silent witness" to corroborate and confirm Majczek's story.

But the closer we look at the photograph, the less certain it appears. All that the picture actually depicts is people walking in and out of the courthouse. The blown-up newspaper, transmitted almost magically across

118. McPhaul \& McGuire, supra note 42 . 
space to take us back in time, situates the photograph as having been taken in a particular and critical moment. It does show that Wanda Skutnik was lying when she said she had never seen Wiecek before identifying him, but Skutnik's lie is not necessarily inconsistent with Wiecek's guilt. It could be that Skutnik lied and Wiecek was guilty: The one in no way precludes the other. Indeed, the mere fact that Skutnik had in fact seen Wiecek prior to her December 23 identification of him does not even prove that her identification of Wiecek as the murderer was incorrect.

The photograph thus impeaches Skutnik's credibility by contradiction, showing by extrinsic evidence that her testimony was inaccurate, at least in one particular. Note that the film has in fact already suggested the importance of contradiction to the evaluation of credibility by both the police and the jury: It was partly Wiecek's own contradictions about minor matters that led to his arrest and subsequent conviction. Now, however, the viewer is supposed to believe that Wiecek's contradictions meant nothing; they were innocent mistakes or trivial mistruths deriving from the pressure of interrogation: As Wiecek explained to McNeal, "When they question you hour after hour, you're bound to get mixed up on a lot of little things, the way I did." Skutnik's contradiction, by contrast, is seen to be positive proof of her perjury. While the film entirely elides the difficult question of when and to what extent inconsistency should impeach credibility, it is true that if Skutnik is discredited, the evidence linking Wiecek to the murder, already gossamer, dissolves entirely. Skutnik's identification was the only substantial proof against Wiecek: Without it, there is no longer sufficient evidence to justify a belief in Wiecek's guilt. In the actual Majczek case, the reporters interviewed some of the jurors who had decided Majczek's fate. All of those interviewed claimed that had they been informed about some of what the Chicago Daily Times had managed to dig up, they never would have convicted Majczek in the first place. ${ }^{119}$ Certainly had such a photograph been displayed to the original jury, the probability of Majczek's conviction would have decreased substantially.

And yet, powerful though the photograph's attack on Wanda Skutnik's credibility may be, the proof offered by the photograph is much more circumstantial and attenuated than the film makes it out to be. It does not in fact speak for itself, but rather requires a context in order to be understood. ${ }^{120}$ Only by understanding why the date matters can we

119. McPhaul \& McGuire, supra note 43.

120. Because of the frequent testimonial use to which photographs are put, photography is often described as possessing narrative qualities. But the crucial element in any narrative is agency, which, in the case of the photograph, may be located in the viewer. The viewer of any discovered photo may endow the image with storytelling abilities. According to Barthes, the most compelling photographs are those that resist the viewer's imposition of a narrative through their "stupidity"--their refusal to "speak." ROLAND BARTHES, CAMERA LUCIDA 9 (1980). For other discussions of the relation between photography and narrative, see W.J.T. MITCHELl, PICTURE THEORY: EsSAYS ON VERBAL AND 
appreciate the significance of the date revealed on the front page of the newspaper. The movement from the photograph to a belief in Wiecek's innocence requires the viewer to make a chain of inferences. Placed into a broader narrative, the photograph shows that Wanda Skutnik's testimony was inaccurate; however, the viewer must therefore infer that her inaccuracy was intentional, a lie rather than a misunderstanding or an honest mistake, and then further infer that a witness who lied about this detail cannot be believed when she identifies Wiecek as the guilty man. Alternatively, the viewer might infer that Skutnik's inaccuracy may have been inadvertent, but that a witness who misremembers whether she had previously seen the suspect cannot be trusted when she claims to remember his identity from the crime scene itself. The point is that although the miraculously enlarged photograph does impeach Skutnik's credibility, it does not, when analyzed carefully, speak dispositively about Wiecek's innocence. The film, however, treats it as if it does, as if the photograph makes Frank Wiecek's innocence self-evident. ${ }^{121}$

The film's resolution of the evidentiary conundrum is problematic from another angle as well. In fact, in actual courtrooms, the photograph lacked the clear-cut authority granted to it in the film. The photographic image had never been granted the legal status of irrefutable proof that the film suggests. Rather, from the time of their earliest use in the 1850s and 1860 s, photographs had often provoked an ambivalent response on the part of judges, who saw them as offering potentially compelling evidence and simultaneously feared the very vividness of their displays. ${ }^{122}$ This

VisUAL REPRESENTATION (1994); and ROLAND BARTHES, The Photographic Message, in IMAGEMUSIC-TEXT, supra note 110 , at 15.

121. Barry Scheck and his co-authors make similar claims for properly administered DNA tests, claims that are, on their face, much more plausible than Northside's claims about the photograph. See, e.g., DWYER, NEUFELD \& SCHECK, supra note 18, at 92 (calling DNA tests "indisputable proof'). But note that even DNA profiling does not necessarily prove innocence or stand outside the narratives produced at trial: For example, the lack of a DNA match may just show that another party was present as well, in addition to the defendant. And proof, even DNA evidence, is almost never "indisputable"; the acquittal of O.J. Simpson (in which Scheck himself was one of the defendant's attorneys), for example, shows how significant quantities of DNA evidence found at the crime scene may be explained in ways consistent with innocence. It is worth remembering that a critical piece of evidence in the civil suit against Simpson was, in fact, a series of photographs: images of Simpson wearing Bruno Magli shoes, the Lorenzo model, at a football game. (Bloody treadmarks from Bruno Magli shoes, the Lorenzo model, in Simpson's size, were found at the scene of the crime, and only 299 pairs of such shoes in the proper size were sold in the United States, and Simpson had denied owning any such shoes.) For the testimony on this photograph and its authenticity, see, for example, the transcripts from the civil trial of O.J. Simpson for Dec. 18 and Dec. 20, 1996, available at http:// www.courttv.com/casefiles/simpson/transcripts/dec/dec18.html; http:/www.courttv.com/casefiles/ simpson/transcripts/dec/dec20.html. Like the photograph in Northside, this image (if believed to be authentic) showed that a witness's statements were incorrect (in this case Simpson's testimony that he had never owned Bruno Magli shoes). The photograph did not, of course, prove that Simpson murdered Nicole Brown Simpson; it simply showed that one of Simpson's testimonial claims was mistaken. Nonetheless, while we cannot know for certain, it seems likely that this photograph, by challenging Simpson's credibility, played a significant role in the jury's finding of liability.

122. Jennifer L. Mnookin, The Image of Truth: Photographic Evidence and the Power of Analogy, 10 YALE J.L. \& HUMAN. 1, 53-59 (1998). 
ambivalent response to the photograph was part of a much broader judicial ambivalence toward technologically-produced ways of knowing that both promised and threatened to provide authoritative knowledge-and thus both promised and threatened to eliminate human judgment from the process of legal fact-finding. (The judicial reluctance to allow the polygraph, as we have seen, also reflects this ambivalence.)

In the case of the photograph as evidence, the judicial response to this ambivalence was to construct a doctrine that deemed the photograph to be mere illustration, rather then independent proof. ${ }^{123}$ Photographs were understood to be the depiction of an eyewitness in visual form, rather than substantive evidence in and of itself. ${ }^{124}$ This doctrine meant that in order to use a photograph, it first had to be "authenticated" by someone who had first-hand personal knowledge of that which was represented in the image. A witness had, in essence, to claim the photograph as his or her own testimony in visual form. Photographs were not generally permitted to serve as "silent witnesses"- they could be used as evidence only when they had a testimonial sponsor, some witness who claimed to have seen whatever was depicted. ${ }^{125}$

A photograph found in a newspaper archive, taken long ago by an unidentified and hence unavailable photographer, enlarged to reveal details unknown to any human being, would, therefore, not have been permitted into evidence by most judges. ${ }^{26}$ While Northside suggests that the photograph can be the evidentiary form that retains its authority both for the everyday man on the street ${ }^{127}$ and within the legal sphere, in fact, the photograph that provided the definitive evidence in the film would have been excluded, like the polygraph, from many courtrooms. ${ }^{128}$

What is most striking about the use of the photograph in Northside is just how comfortable, how sanguine, the film seems to be about its

123. Id. at $43-45$.

124. See, e.g, 1 John Henry Wigmore, A TREATISE ON THE SySTEM OF EVIDENCE, $\S 790$ (1 st ed. 1904).

125. Mnookin, supra note 122 , at $43-45$.

126. The on-the-ground realities were more complicated. Although doctrinally, photographs were understood as merely illustration, in fact, as courts sometimes recognized, they were, once admitted, also treated as if they had independent probative value. See id. at 47-50. However, it was only with the advent of the $x$-ray that judges had to construct grounds for admissibility that emphasized that the authority of visual evidence might come from the process by which it was made rather than because of authentication by a witness. On the important shift that occurred with the rise of $x$-ray evidence, see Jennifer Mnookin, Images of Truth: Evidence, Expertise and Technologies of Knowledge in the American Courtroom 367-404 (1999) (unpublished Ph.D. dissertation, M.I.T.) (on file with M.I.T. Library and with the author). 72 .

127. Given Northside's gendered conception of proof, we use "man" advisedly. See supra note

128. This of course does not mean that it would have been excluded from a Board of Pardons hearing, where the formal rules of evidence that govern trials would not in fact have applied. But Northside makes no distinction between the evidence that might be received in different legal settings, and generally constructs "legal evidence" and "evidence admissible in court" as equivalent. 
authority. In stark contrast to most noir films that examine the meaning or truth-value of the photograph, Northside urges no cautions regarding the photograph in particular, nor technologically produced knowledge more generally. ${ }^{129}$ Rather, the film celebrates and even glorifies technological processes as offering privileged access to truth, access even (as with the polygraph) to the seemingly impenetrable interiors of the human mind. The film archly criticizes the legal system for resisting these technologies, for failing to recognize that they are superior to the imperfect and corruptible lay eyewitness who reports what she allegedly saw. ${ }^{130}$

As a reenactment, Northside's claims to epistemological authority are necessarily precarious, and it is the photograph that acts as a warrant, warranting that we can indeed believe what we see. The photograph becomes a stand-in for the film itself: The authority of the photograph buttresses the authority of the film. And at the plot level, the photograph quashes all dissent, carrying every reasonable viewer inexorably toward the conclusion that Frank Wiecek is innocent. It is the photograph alone, among all the forms of evidence displayed in the film, that can compel conviction by operating as legitimate evidence both within the legal arena and outside of it.

In the end, however, it is precisely the film's strong realist claims that undermine its defense of machine-made knowledge. For as we have seen, the crowning moment of technological triumph, the development of the photograph that confirms a man's innocence and persuades doubters, is a fiction. By turning to a blatant fiction at the most critical moment of the film, Northside undermines its own authority, revealing that in fact its own representation of the case cannot necessarily be trusted. This climactic scene manifests the disjunction between seeming real and being real, the tension between verisimilitude and evidence. These tensions in turn rehabilitate the legal system's hesitation and ambivalence regarding technologically-produced forms of evidence, a hesitation borne, in part, precisely out of the fear that machine-produced vision risks looking more real than the real itself, that visual evidence may be too persuasive, too compelling.

And yet, as we shall see next, many judges during the 1930s and 1940s were more easily seduced by the moving image than their predecessors were by the photograph. Perhaps this suggests that the courtroom and the cinema may share more in common than we might think.

129. See Nancy West \& Penelope Pelizzon, Smile, My Lovely: Photography, Film Noir, and Identity (2001) (unpublished manuscript, on file with authors).

130. In this sense, Northside follows classical film narrative's tendency to make the individual into a heroic figure. Like the Western hero or the private detective, McNeal is portrayed as emerging triumphant over rigid social forces by following his own instincts and codes of conduct. For further discussion of this point, see Rosenberg, supra note 19, at 284-85. 


\section{FILM AS LEGAL EVIDENCE}

So far, this Article has striven to show how Northside is a film that centers upon questions of evidence. On the one hand, the film itself is a study in evidence. It interrogates three distinct modes of proof, critiques legal conceptions of evidence, and concludes by offering up the photograph as the evidentiary ideal, a seemingly "pure" form of knowledge that retains its power even when it is enlarged, sent over a wire, and reconstituted somewhere else. On the other hand, as a reenactment, Northside sets itself up as evidence, or, at a minimum, as a true retelling of an actual case. That is, recognizing Northside's status as a reenactment invites precisely the same questions Northside asks about proof, but this time at a meta-level. What makes a filmic depiction credible? What makes the viewers of Northside know that even if Northside isn't "real," it indeed portrays "real" events in a manner that can be trusted? Do not be misled-while the film is simultaneously fact and fiction (just as the photograph in the film is both the critical fact and itself a fiction), Northside is not, in fact, particularly reflexive. Rather than interrogating its own authority or generating skepticism about the possibilities for knowledge, the film simply wants viewers to believe in its authority. ${ }^{131}$ In short, the film is about two spheres of evidence, the lay and the legal. The film portrays the limits of legal evidence-the willingness to be satisfied by unreliable eyewitness testimony, the unwillingness to see the evidence of machines of judgment. It shows both the unrivalled persuasive power of visual proof and reveals that finding the proof that will satisfy the law can be a serendipitous enterprise. At the same time, while the film is neither documentary nor fiction, it is itself a form of proof. It is designed to be a persuasive rendition of a true story of justice nearly denied, revealing indisputably both Frank Wiecek's innocence and the precariousness of justice. Reenactments, we might say, offer a kind of lay evidence. As one of the advertisements for the film on Northside's press sheet put it hyperbolically, "Every word is true." 132

And so, in this final section of the Article, we will turn to look at the third side of this triangle of evidence: films as legal evidence. We shall see that there are, in fact, interesting parallels between Northside's claims about visual proof and the reception of films in actual courtrooms. Just as Northside's credibility, both at the plot level and as the reenactment of a true story, depends on retaining a certain naïveté about the meaning of the visual image, judges who confronted filmic evidence elided the complexities of the form. Moreover, the conflation between the

131. Our reading of the film, in this sense, departs substantially from that of Telotte, who sees Northside, as well as other noir documentaries, as possessing a great deal of self-reflexivity. See TELOTTE, supra note 16, at 141.

132. Exhibitor's Campaign Sheet, supra note 50. 
photograph and the film, implicit in Northside, becomes explicit when films become a form of legal proof. Finally, on those few occasions when filmed reenactments were used in trials, they were often seen to be as powerful as the real thing. Actually, these filmed reenactments were even more successful at operating simultaneously as fiction and as fact than Northside, not only standing in for the actual event but offering a form of proof that was seen to be, in fact, superior to it.

Films were offered into evidence in court as early as 1913-merely seventeen years after the first motion pictures were displayed to audiences. For the next twenty years, juries in a number of states viewed the occasional film in evidence, but few appellate courts ruled on their admissibility. Though films appear to have been used without objection on occasion in trials, the only two reported appellate cases before the end of the 1920s that analyzed their use both supported their exclusion.

The earliest appellate case to examine the admissibility of a film was Gibson v. Gunn, decided in $1923 .{ }^{133}$ The plaintiff was suing to recover for damages resulting from having been struck by the defendant's automobile. The plaintiff was a vaudeville dancer who, at some point prior to the current accident, had lost his leg and had been forced to use a prosthesis but was nonetheless able to continue in vaudeville with his artificial leg. $\mathrm{He}$ displayed to the jury a motion picture that he used as the opening entertainment in his vaudeville show; the film portrayed the plaintiff on crutches, walking into a shop that sold artificial limbs, and leaving the store walking under his own power. In the following scene, he encountered two friends, dancers who performed certain tricks - the plaintiff performed these same tricks as well as other stunts that his ablebodied buddies viewed as too difficult for them. ${ }^{134}$ Though the opinion does not detail the plaintiff's motivation for displaying the picture, presumably he wanted the jury to see how competent and sure in movement he was despite his artificial leg, in order to rebut either an explicit or implicit claim that his new injuries did not cause him much additional damage or loss in income considering his prior one-legged condition.

Whatever his justification for showing the film, the appellate court was not impressed. The opinion deerns the admission of the film "a radical departure from the rules of evidence," notes that "moving pictures present a fertile field for exaggeration of any emotion or action," and complains that no evidence was presented "as to how this particular motion film was prepared." 135 Worse, the film "brought before the jury irrelevant matter, hearsay and incompetent evidence, and tended to make a farce of the

133. Gibson v. Gunn, 202 N.Y.S. 19 (1923).

134. Id.

135. Id. 
trial." It is as if the performer had performed on the wrong stage: "The plaintiff's ability as a vaudeville performer was not the issue, and his eccentric dancing, comic songs and the dialogue and remarks of his fellow-performers had no place in the trial in the Supreme Court of the state." ${ }^{136}$ While some of their specific criticisms of the film are not without merit (one might, for example, be legitimately concerned about the lack of proof of how the film was made and about the fact that the statements made by the vaudevillian's buddies within the film may have been hearsay), the judges' discomfort does not seem to stem from these particular concerns, but rather from something deeper and less inchoate. Showing a film at a trial? A vulgar entertainment in the arena of judgment, vaudeville theater invading the theater of proof? It is more than the judges can bear. They say so themselves: The film threatened to make the trial itself into a farce.

The next appellate discussion of an attempted use of film also came down in favor of exclusion. This case, decided in 1926, involved alleged stock fraud. ${ }^{137}$ One of the issues in the case was whether glass caskets could feasibly be manufactured; the defendant sought to introduce a film that purported to show the actual manufacture of these caskets at the defendant's Oklahoma plant. The trial court refused to allow the defendants to show the film, declaring, "A motion picture does not of itself prove an actual occurrence. The thing reproduced must be established by the testimony of witnesses." 138 The court said that determining whether the film was sufficiently verified to warrant its admission was up to the trial court. But the opinion then offered a circular argument, one that, if taken at face value, would mean that the exclusion of a motion picture as evidence could never constitute error: "[I]f, as contended by counsel for appellant, the testimony relative to the process of manufacture completely verifies the picture, then he cannot successfully claim injury from the refusal of the court to repeat this testimony by a moving picture display of the facts already in evidence."139 Essentially, the court suggests, quite reasonably, that a film has to be verified by testimony to be admissible. But if testimony verifies the film in every particular, then the exclusion of the film cannot harm the party, for it is by definition cumulative - what the film shows is already in evidence, through the testimony necessary to verify the film in the first place. A film is thus either insufficiently verified or inherently cumulative.

Unfortunately, the opinion in the case provides little detail on the facts underlying the criminal charges. One imagines, however, that the trial judge may have been concerned that the perpetrators of an elaborate stock

136. Id.

137. De Camp v. United States, 10 F.2d 984 (D.C. Cir. 1926).

138. Id. at $984-85$.

139. Id. 
fraud might well have also "manufactured" a film showing the company's manufacturing plant. The film might have been authenticated, in the sense that a witness vouched for its accuracy, and yet nonetheless be nothing more than fiction. The circular approach taken by the appellate court thus provides a tool for upholding the exclusion of a film of dubious reliability by giving the trial judge unlimited discretion. The appellate court does not merely think the trial court had the discretion to exclude the film; it views the trial court as having been right to exclude the film: "[T]he admission of the motion picture would have amounted to nothing more than a spectacular display of a situation based upon facts in evidence." 140 The tone of this opinion is far less outraged than that of Gibson v. Gunn, but we still see hints of the same concern: A film may be a "spectacular display" that debases legal process and turns the courtroom itself into a spectacle.

Films as spectacles: This observation demands pause for reflection. Spectacle is part of a long tradition of popular forms, such as the circus or magical acts of traveling fairs dating back centuries. ${ }^{141}$ Spectacles are sensational; they are designed to provoke sensation, to appeal to the viewer's emotions. It is this sensational response that the judges are leery of, and while their reaction may be unduly alarmist, it reflects a serious concern: that films may be so powerful, so persuasive, that they will carry along the viewers toward a conclusion that would not be warranted by reason. In fact, we can tease out three separate anxieties: first, that films as evidence may cheapen the trial, demeaning its seriousness by importing a form of popular entertainment, delegitimating verdicts by association with vaudeville. Second, that evidentiary films may encourage juries to make determinations based on emotion rather than reason. (Jurors may be lured by sensation and fail properly to sift the evidence.) Third, that films carried the risk of seeming too real, eliminating the distance between a representation and the actual event. Leading evidence scholar John Henry Wigmore cautioned judges about this risk in the 1923 edition of his treatise on evidence: "Theoretically, of course, the motion picture can never be assumed to represent the actual occurrence.... And yet, any motion picture is apt to cause forgetfulness of this and to impress the jury with the convincing impartiality of Nature herself." 142

The opinions of these early judges, however, do not represent the approach that came to typify judicial response to motion picture evidence. For the most part, those judges who were faced with this new

140. Id.

141. Much has been written on the cultural history and operation of "spectacles." See, e.g., Jonathan CRARY, TECHNIQUES OF THE OBSERVER (1993); Jean-Luc Comolli, Machines of the Visible, in THE CINEMATIC APPARATUS 121 (Stephen Heath \& Teresa de Lauretis eds., 1980); and Elizabeth Cowie, The Spectacle of Actuality, in COLLECTING VISIBLE EVIDENCE, supra note 66, at 19. 142. 2 WIGMORE, supra note $98, \S 798$. 
technological form of proof resisted the notion that films as evidence raised any complicated evidentiary or interpretive questions. The typical response was simply to analogize the film to a collection of photographs, and to argue that, since photographs were admissible so long as a proper foundation was established, then films should be as well. There was, to be sure, still occasional continued discomfort with the "spectacular" nature of film, as well as soft murmurs of concern over whether film might be too lifelike a medium, too vivid and too convincing. But these moments of anxiety were the exception. Most of the time, judges saw movies as nothing more than a series of still photographs, a sequence of individual frames made into one seamless whole, and they saw the whole as no more and no less than its constituent parts.

The basic logic is well illustrated, for example, by a 1937 California case, Heiman v. Market: "[I]t is established beyond question that photographs may be admitted in evidence, that moving pictures are but a series of single pictures, and that as single pictures may be received in evidence, there is no reason why moving pictures may not be admitted."143 The description of film as a "series of photographs" is obviously intended to make filmic evidence unproblematic, for by the 1920s, photographs had been regularly used as legal evidence for more than forty years. More importantly, this rough equation of film with photography serves to minimize film's "spectacular" quality - taming film, as it were, into possessing one of the most desirable characteristics for the courtroom: immobility. It suggests that the viewers of cinematic evidence possess more control over what they watch than they actually do, since photographs, because they depict one frozen moment in time, allow for careful and repetitive inspection far more easily than films do. And, by linking film with photography, the description also capitalizes on the latter's historical associations with accuracy and objectivity, a point to which we will return shortly.

Unlike the two early judges who were repelled by films as evidence, then, most of the judges who considered them were quite taken with the extraordinary probative value of the proof they offered. And though Wigmore's warning that the representation might be mistaken for the real was frequently cited, it was generally not viewed as a reason to exclude the film from evidence. What accounts for the surprising lack of anxiety about filmic evidence? Why did the early concerns-that films were frivolous, spectacular, and too persuasive-come to seem less pressing?

We shall return to this question at the conclusion of this Section, but we can begin to offer one answer here: Judges may have been influenced by the particular nature of the films that were used in the courtroom. Most of the motion pictures that made their way into evidence in the 1930s and

143. Heiman v. Market, 69 P.2d 178 (Cal. App. 1937) 
1940s fell into two broad categories. The vast majority were films taken surreptitiously by insurance companies (or other defendants), exposing the plaintiff as a malingerer who was overstating or downright faking injuries. ${ }^{144}$ Or, on occasion, they were reenactments or recreations of matters at issue in the trial, including, in a few instances, filmed reenactments of the crime itself. For reasons that we shall explore, both of these sorts of films seemed especially "safe" to use as legal evidence, seemingly exempt from the concerns that led a few early judges to voice serious concern about the use of filmic evidence.

Judges generally allowed defendants to present motion picture evidence that revealed that a plaintiff's injuries were less severe than the plaintiff claimed. ${ }^{145}$ Indeed, some appellate courts found that if such a film had been properly authenticated, its exclusion constituted reversible error. In Boyarsky v. Zimmerman, a plumber working on a building was hit on the head by a bolt that crashed down from fifty-five feet above, where steelworkers, employed by a different subcontractor, were also at work. Eight months after the accident, the defendant secretly filmed the plaintiff walking along the street carrying a parcel, in order to show that the "plaintiff's claim that he was physically incapable of working was untrue." 146 The court writes,

In view of the claim of the plaintiff that he was totally disabled and unable to work or earn a living at any useful employment this case is a striking illustration of an instance where moving pictures are not only admissible but very important.... In the present case the defendant, appellant, properly points out that the pictures taken of the plaintiff, who contends that he received very severe injuries, will show that he went to live in another city and there evidently conducted himself as a perfectly well man instead of the invalid

144. This courtroom use of surveillance film constitutes the logical outcome of nearly fifty years of using photography and film to make private and furtive acts public. As the work of film scholar Tom Gunning has shown, a series of interlocking inventions-beginning with the invention of the "detective camera" in the early 1880 s-came to popularize the use of surreptitious picture-taking as entertainment. Indeed, as Gunning points out, cinema was "born out" of this form of entertainment, since actuality-films, rather than fictional films, constituted the main product of the cinema for over ten years. Within this climate, Gunning writes,

The apparatus of the cinema allows the passage from private to public space, and its role as simultaneously witness and record endows it with a juridical effect, providing both evidence of wrongdoing and the occasion for judgment and punishment. The viewer of the film negotiates this propulsion of private deeds into public exposure, positioned as both voyeur-witness and moral judge through the surrogate apparatus.

Tom Gunning, Embarrassing Evidence: The Detective Camera and the Documentary Impulse, in COLLECTING VISIBLE EVIDENCE, supra note 66, at 46, 46 (1999).

145. See also Kortz v. Guardian Life Ins. of Amer., 144 F.2d 676 (10th Cir. 1944); Bethlehem Steel v. Foy, 108 P.2d 698 (Cal. App. 1940); Heiman v. Market, 21 Cal. App. 2d 311 (1937); Wallendorf v. N.Y. Life Ins., 12 S.2d 585 (Fl. 1943); Equitable Life Assur. Soc. v. McDonald, 134 S.W.2d 953 (Ky. 1939); Denison v. Omaha 7 C.B. St. R. Co., 280 N.W. 905 (Neb. 1938); Mason v. Evans, 69 A.2d 33 (N.J. Sup. 1949).

146. Boyarsky v. Zimmerman, 270 N.Y.S. 134 (1934). 
which he claimed to be. ${ }^{147}$

On occasion, judges allowed these secret movies even when the defendant "entrapped" the plaintiff into conducting the activities that were filmed. First, it is worth quoting at length the detailed description of the film in one of these cases, to see just how damning these motion pictures could be:

The first picture shows the plaintiff at a golf course, what is commonly called a driving range. He and his lady friend are using a bucket of balls and the plaintiff especially, is driving the balls out into the field. The plaintiff stoops over to take a ball out of the bucket or basket, places it on a tee and strikes the ball with splendid form and carry through. The plaintiff is next seen tossing a basketball. Next he is seen throwing baseballs at a doll rack, or some similar device. Next he is rowing a boat. He is next seen at the lake front preparatory to going swimming. He had his swimming trunks on under his clothes, and the camera discloses that he undressed at the beach, but was not wearing his leather jacket. He and his blonde lady friend go in swimming, and he is shown teaching her how to swim, and lifting her almost out of the water, and as the picture ends it is as though he were rescuing her from drowning, with his left arm under her chin and supporting her and swimming around with his right arm. ${ }^{148}$

So much for the plaintiff's claims of incapacity.

The plaintiff, however, claimed that he had only engaged in these activities because the woman who also appeared in the film had urged him to, and that (unbeknownst to him at the time of their frolicking) she was actually an agent of the defendant. The court was not impressed: "We do not think it is material what part this girl took in persuading the plaintiff to do what the pictures disclose he did do. The pictures speak for themselves and show that the defendant could do things that he claimed at the trial he could not do."149 The pictures speak for themselves: They impeach the plaintiff, showing his testimony to be composed of lies, just as the photograph in Northside seems to show that Wanda Skutnik lied upon the stand.

These movies, taken secretly and then made public before the jury, are particularly interesting because they reveal the theatrical aspects of all legal proof. They show up plaintiffs as actors: When they appear in court, looking ragged or stooped, injured and miserable, they may simply be putting on a show for the jury. Is the seemingly injured plaintiff a genuine

147. Id.

148. McGoorty v. Benhart, 27 N.E.2d 289 (Ill. App. Ct. 1940).

149. Id. Courts did occasionally evince some concern that defendants could "entrap" plaintiffs into appearing on film, but the courts usually admitted the film evidence nonetheless. See, e.g., Maryland Cas. v. Coker, 118 F.2d 43 (5th Cir. 1941). 
victim, or merely a malingerer? Can the jury be trusted to tell exactly which plaintiffs are acting, to separate fact from fiction? The films taken by detective agencies and other commercial filmmakers let the jury spy on plaintiffs when they are unsuspecting, going about the daily business of life. There is a certain irony in using film - the medium of actors-to reveal what these plaintiffs are like when they are not posing for a jury. ${ }^{150}$

These films did not seem to be spectacles themselves: In fact, the subjects of the film did not even know that their actions were being caught on film, and clearly there was no risk that they were playing to the camera or unconsciously influenced by the presence of the recording instrument. Rather than appearing as spectacles themselves, these films revealed the spectacular aspect of the plaintiff's in-court behavior. They showed that the plaintiff was playing to the jury's sympathies, preying on emotion and sensation. These films seemed to bring reality into the courtroom; to exclude them would have meant allowing the plaintiff to stage a dramatic performance unchecked and unconstrained by the contradictory evidence of his or her actual out-of-court behavior. Given this choice between allowing the film into evidence and allowing the plaintiff to dramatize with impunity, it is not surprising that judges almost always saw these films as legitimate evidence.

Reenactments were not nearly so common as these spy films; in fact, there are only a handful of appellate decisions discussing their use in the 1940s. But occasionally, defendants would, astounding though it may seem, agree to reenact their own crimes for the police and before the camera. In one such case, there had been a fatal shooting at DiCioda's liquor store in Los Angeles in 1947. The defendants allegedly committed another robbery a few hours later, and then, when the police stopped them to ask some questions a few weeks later, they shot and wounded one of the officers. Six weeks afterward, they were arrested, and implicated themselves in the liquor store homicide. They also agreed to reenact their crime and have this reenactment recorded on film. At trial, the defendants repudiated their confessions, and claimed that they had made them under coercion. ${ }^{151}$ The three motion pictures-each one showing a reenactment of one of the alleged crimes, the homicide, the robbery, and the shooting of the police-were shown at trial. Testimony was introduced to show how the films were set up and made:

150. These courtroom films are a version of cinema vérité; like vérité they endeavor "to render the film-making itself invisible and to give viewers the sense of unmediated access to the contingencies of an actuality uncompromised by the camera." CORNER, supra note 67 , at 44 . One of the key qualities of vérité, it has been argued, is "a firm commitment to the 'evidentiality' of film." Id. Comer further argues that the reenactment (or, in his terms, the drama-documentary) and vérité together "put pressure on documentary 'look' and 'truth' by developing specific generic characteristics and aspirations to an extreme degree," though obviously in quite different ways. Id. at 55 . It is interesting to recognize that the two forms of films used as legal evidence are precisely those kinds of films that both partake in and problematize documentary's naïve claims to truthful depiction.

151. People v. Dabb, 197 P.2d 1 (Cal. 1948). 
There was first a rehearsal of each incident, at which the defendants were asked to show what they had done. From this it was determined where the camera should be set up in order to embrace all of the action, and the entire scene was then photographed, with the sound and pictures being simultaneously recorded on the same strip of film. ${ }^{152}$

The court noted that motion pictures are susceptible to fabrication, but thought that the way to handle this risk was by requiring adequate foundation evidence to establish that the film was properly taken, developed, and not tampered with, as a prerequisite to admissibility. The court further recognized that films might be misleading, or unduly vivid, but emphasized that a voluntary reenactment was unlikely to suffer from these dangers:

A motion picture of the artificial recreation of an event may unduly accentuate certain phases of the happening, and because of the forceful impression made upon the minds of the jurors by this kind of evidence, it should be received with caution. ... However, when the events which are being photographed consist of a voluntary reenactment by the accused of what occurred, there is little, if any, danger of misleading emphasis which is unfavorable to him. Moreover, as a method of presenting confessions, sound motion pictures appear to have a unique advantage in that, while presenting the admission of guilt, they simultaneously testify to facts relevant to the issue of volition. ${ }^{153}$

It is worth dwelling for a moment on the strangeness of these reenactment films. Why, one wonders, would a criminal suspect agree to let the police make a movie of his crime? Is he or she lured by the desire to play a starring role in a two-bit drama? Is it the same dynamic that drives criminal suspects to confess: an urge to tell their stories, an urge for someone to know what has happened? ${ }^{154}$ In some of these films, the criminal suspects and the police return together to the actual scene of the crime, and sometimes a cop plays the victim, the police and the perpetrators performing together in a spectacle of proof. ${ }^{155}$

What exactly are these reenactments? They are, in fact, spectacles of proof. They are extremely persuasive evidence that the defendant committed the crime because they simultaneously show and tell: They literally show the defendant committing the crime, and they also show, by the fact of their existence, that the defendant was willing to tell everyone that she or he committed the crime. They are not just proof, but also

152. Id. at 7-8.

153. Id. at 9 .

154. For an analysis of the role of the confession in law and literature, see PETER BROOKS, TROUBling CONFESSIONS: SPEAKING GUILT IN LAW AND LITERATURE (2000).

155. See, e.g., People v. Rowe, 99 Cal. App. 3d 1023 (1975). 
spectacle: a compelling display before the jury of the police and the criminals together engaged in a form of cinema vérité. As reenactments, these films show the jury what it was like when the defendant committed the crime. His actions are replayed before the jury's eyes, turning the jurors into virtual witnesses ${ }^{156}$ to the events underlying the trial. Of course, these reenactments do not "actually" reveal what the crime looked like; they are post-hoc representations, not filmed depictions of the event itself. In fact, though, they may offer even more persuasive evidence than a film that actually caught the criminal in the act. Films that capture the actual moment on camera might indeed be powerful evidence-but they are subject to reinterpretation, or to reinscription within a larger narrative, or to analysis that makes what looks clear on film seem more complicated or muddy once it is explained or contextualized. ${ }^{157}$ By contrast, when a suspect agrees to participate in a reenactment of his own crime, it is a form of confession, but a confession by demonstration rather than simply by words. Of course, such a film could itself be placed within a larger context (as those defendants who claimed coercion were attempting to do), but it is hard to make such a context stick, for the films themselves demonstrate the defendants' guilt. ${ }^{158}$

Courts continued, on occasion, to register discomfort about the "spectacular" nature of filmic evidence. In a case where the appellate court insisted that a film be excluded because it was misleading, the judge writes dryly, "Doubtless the show was highly entertaining to the jury, but entertainment of the jury is no function of a trial. And why all this fuss to prove a fact susceptible of easy, exact, and indisputable demonstration by actual measurement?"159 But for the most part, courts seemed complacent about cinematic evidence, confident that films, becoming ever more popular as a medium of news and entertainment, could offer reliable evidence in court as well. They were appreciative of the evidence that

156. The term "virtual witness" is borrowed from STEVEN SHAPIN \& SIMON SCHAFFER, LEVIATHAN AND THE AIR PUMP (1985).

157. The acquittal of the officers in the state criminal case resulting from the beating of Rodney King is an obvious example of how a videotape that seems upon first viewing to show something clearly-in this instance the use of excessive force by the police-can be read differently when it is explained frame-by-frame. See, e.g., Kimberlé Crenshaw \& Gary Peller, Reel Time/Real Justice, in READING RodNEY KING/READING URBAN UPRISING 56 (Robert Gooding-Williams ed., 1993); Chuck Hagen, Photography View: The Power of a Video Image Depends on the Caption, N.Y. TIMES, May 10, 1992, §2, at 32; How the Defense Dissected the Tape, NEWSWEEK, May 11, 1992, at 36.

158. Reenacted depictions of the crime, like any other form of confession, might of course be false. On the phenomenon of the false confession, see Saul M. Kassin, The Psychology of Confession Evidence, 52 AM. PSYCHOLOGIST 221 (1997); Saul M. Kassin \& Katherine Keichel, The Social Psychology of False Confessions: Compliance, Internalization and Confabulation, 7 PSYCHOL. SCI. 125 (1996); Richard J. Ofshe \& Richard A. Leo, The Decision To Confess Falsely: Rational Choice and Irrational Action, 74 DENV. U. L. REV. 979 (1997); and Richard J. Ofshe \& Richard A. Leo, The Social Psychology of Police Interrogation: The Theory and Classification of True and False Confessions, 16 STUD. L. \& SoC'Y, 189 (1997).

159. Hadrian v. Milwaukee, 1 N.W.2d 755 (Wisc. 1942). 
films could offer - seemingly direct access to critical matters ranging from the way the crime was actually committed to the plaintiff's actual physical condition-and were strikingly unconcerned about distortion, either the distortions that might be present within the filmic representation, or distortions of the trial process that might result from the growing use of such "spectacular" evidence. Of course, trials can be spectacles themselves, and the presentation of evidence is a show that one side puts on before the factfinder; in this sense, filmic evidence within a trial is like a play-within-a-play. But filmic evidence walks a very fine line between fact and fiction, between reconstruction and representation. Like the filmed reenactment of Northside, a film made in order to be legal evidence is simultaneously real and unreal, documentary and drama.

We will return now, at more length, to the central puzzle raised by this brief look at the use of actual films as legal evidence: Why did judges overcome their early concerns about this spectacular form of proof and decide that films were a legitimate form of proof? It is tempting, fifty years later, to position these judges as naïve - too easily awed by visual technology to see through it. If such a reading is fair, a certain irony emerges, given that photography, in its early days, received a substantially more critical evaluation from judges. Why, in other words, would latenineteenth-century judges express such informed skepticism about photographic authority, while their counterparts some decades later were relatively sanguine about filmic evidence?

We will offer four arguments, all of them admittedly speculative, for why judges latched onto filmic evidence relatively uncritically. First, judges may have been influenced by the contemporaneous emergence of a form of film that claimed to offer truthful representation: the documentary. In fact, shortly before judges were starting to embrace film as possessing the authority of a "series of photographs," the documentary movement had begun its development in Britain and the United States. ${ }^{160}$ From its very beginnings, the rhetoric surrounding the documentary film focused on such key concepts and nouns as "knowledge," "information," "sobriety," "objectivity." The intention, of course, was to associate documentary film with the serious, to position it - along with law, science, and other information-oriented fields - as what Bill Nichols calls a "discourse of sobriety." 161 In so doing, documentary filmmakers even referred to their individual films as "possessing all the authority and close attention of the photograph. ... [O]ur aim is not to offer light entertainment but to show the raw truth, exposed and frozen forever as image, just as Jacob Riis and

160. The date of "origin" for the documentary movement is generally accepted as 1926, the year in which the leading figure of the movement in Britain and America, John Grierson, coined the term. See BILL NICHOLS, REPRESENTING REALITY: ISSUES AND CONCEPTS IN DOCUMENTARY 4 (1991).

161. Id. at 2 . 
others have done with their photographs." 162 This echo of the very description deployed by judges to legitimate films as evidence (film as a "series of photographs")-an echo that we can hear in other descriptions of documentary film as well-alerts us to the possibility that the documentary movement may, in fact, have helped shape legal notions about the evidential usefulness of cinema. Between the late 1920s and early 1940 s, the documentary film enjoyed a powerful reputation in American culture as objective, earnest, and trustworthy - characteristics which proponents of the movement reinforced by setting the sobriety of the documentary against the "spectacle" of mainstream Hollywood cinema. ${ }^{163}$

Yet, as film scholar Elizabeth Cowie describes, even documentary films, simply because they are films, possess elements of the spectacle. "For all its seriousness, the documentary film nevertheless also involves more disreputable features of cinema usually associated with the entertainment film, namely, the pleasures and fascination of film as spectacle." 164 These pleasures arise not through make-believe or fictional enactment but by the representation of actuality. Thus, inherent in the viewing of any film, no matter what its purpose, audience, method, or genre, are two desires: a desire for reality captured, securely contained for dissection and analysis, and a desire for the real not as knowledge but as image, as spectacle. In the early days of the documentary movement, however, such a recognition was rarely articulated; what was articulated, over and over again, and often by analogy to photography, was the documentary's seriousness of purpose. And, while the judges of the two early appellate cases anticipated Cowie's observations by warning the legal community of film's "spectacular" nature, later judges-those writing some time after the development of documentary film in America-seemed willing enough to see film as a "discourse of sobriety." Whether or not judges were in fact influenced by the rise of documentary filmmaking, surely documentary filmmakers could not have asked for a more powerful alliance.

The second argument for why judges came to accept filmic evidence with relative ease is quite straightforward: By analogizing films to photographs, judges made the film into a comprehensible-and

162. Id. at 7; see also ERIK BARNOUW, DOCUMENTARY: A HISTORY OF THE NON-FICTION FILM 254-55 (1974) (discussing these analogies to photography).

163. As Bill Nichols observes, "A deep-rooted response in documentary filmmaking has been vigorous disassociation from the distracting shadow-play of fiction. Early documentarists were particularly vehement in their judgments of the fiction film." NiCHOLS, supra note 160 , at 4 . Among these filmmakers were Dziga Vertov and John Grierson, who "drew harsh and unflattering comparisons between the fiction film industry and both the formal potential of cinema and the social purpose of the documentary. They lambasted Hollywood as a symbol for escapist, meretricious spectacles." Id.

164. Cowie, supra note 141 , at 19. 
admissible - form of evidence. If photographs were admissible (and they long had been so) and films were nothing more than a series of photographs, then films did not pose tricky problems of categorization or analysis. This process of analogizing the new to the known is, of course, a mainstay of legal reasoning as well as a commonplace judicial reaction to new technological forms. ${ }^{165}$ In fact, when confronted with the photograph decades earlier, judges made a similar conceptual move: They analogized the photograph to maps, models, and diagrams, thus making the new into the familiar. ${ }^{166}$

Analogical reasoning, however, involves emphasizing similarity and eliding difference. If $x$ can be analogized to $y$, it means that the two items are the same in all the ways that count; the battleground, of course, becomes determining which, exactly, are the ways that count. When judges analogized photographs to drawings, the analogy foregrounded the ways in which the photograph was a constructed representation, a human creation rather than a mirror of nature. It was, in significant part, this analogy that led judges to resist any simplistic notion of the photograph as an unmediated depiction of the real. ${ }^{167}$ Over time, as photographic admissibility became taken for granted, the power of the analogy faded, and judges began to see the photograph both as an illustration and, at times, as a silent witness. ${ }^{168}$ Still, the key point is that the analogy circumscribed the way that the photograph was understood. The analogy between films and photographs may have had a similar circumscribing effect. It provided judges with a way to ignore some of the differences between photography and film: that films captured movement and the passage of time instead of a single instant; that films were typically edited into their final form; that the process of "reading" a film was less familiar to a lay juror than "reading" a photograph. But even this list is misleading,

165. For the classic account of case-by-case reasoning in the law, see EDWARD H. LEVI, AN INTRODUCTION TO LEGAL REASONING (1949). For how analogy operates in legal discourse, see, for example, Scott Brewer, Exemplary Reasoning: Semantics, Pragmatics, and the Rational Force of Legal Argument by Analogy, 109 HARV. L. REV. 925 (1996); Cass Sunstein, On Analogical Reasoning, 106 HARV. L. REV. 741 (1993).

166. Mnookin, supra note 122, at 24-27, 45-50, 54-55.

167. In this sense, legal discourse was vastly different from other nineteenth-century discourses, which tended to exaggerate the novelty of photography as a medium. As photo historian John Tagg notes, "What is striking in the earliest articulated responses to the invention and dissemination of photography is how often the images it began to pour forth are hailed (or altematively denounced) as a totally new currency, not only quantitatively but qualitatively different from any previous kind of image production." JOHN TAGG, GROUNDS OF DisPUTE: ART HISTORY, CULTURAL POLITICS, AND THE DISCURSIVE FIELD 122 (1992).

168. See, e.g., People v. Bowley, 382 P.2d 591, 594 (Cal. 1963) (declaring that photographs can be "silent witnesses" that provide substantive evidence and not merely illustrate someone's testimony); Sisk v. State, 204 A.2d 684, 685 (Ct. App. Md. 1964); John H. Anderson, Jr., Admissibility of Photographs as Evidence, 7 N.C. L. REV. 443 (1929) (suggesting that a case excluding a photograph as substantive evidence was incorrectly decided); Dillard S. Gardner, The Camera Goes to Court, 24 N.C. L. REV. 233, 245 (1946) (arguing that photographs properly verified can be silent witnesses). 
for the power of the analogy was to make analysis of the similarities and differences between films and photographs optional. Judges could, and often did, simply make the analogy and then admit the film, as if it were syllogistic logic in action: Photographs, when verified by an attesting witness, are admissible; films are a series of photographs; therefore, films, when verified by an attesting witness, are admissible.

The third argument for why judges became comfortable with filmic evidence focuses on the particularly persuasive power of the types of films-surveillance films and reenactments-that were used in the courtroom. We have already discussed this point, so we shall simply recap briefly here. Surveillance films carried the weight of exposure; reenactments, when performed by the actual criminals, carried the weight of confession. To have excluded surveillance films would have been to allow the plaintiff to lie with impunity. These films, instead of seeming fictional or spectacular themselves, seemed to reign in otherwise dangerous, in-court performances of injury.

Further support for the argument that judges admitted filmic evidence because of the particularly persuasive nature of the films involved can be gleaned by recalling those films that were excluded from evidence, such as a manufacturing process that might never have existed, and a vaudevillian's opening act. When the films themselves seemed to be either fictional creations or performances, judges barred them. ${ }^{169}$ When the use of fiction in court became too obvious, judges resisted because one of the fictions of law is that trials are places for the determination of facts, not (or at least not merely) the construction of stories. ${ }^{170}$ So long as films promised to counteract other fictions - the fiction of the injured plaintiff, the fiction of the innocent defendant-they were a legitimate and desirable form of evidence, for they could provide tales of truth rather than encouraging flights of fancy.

Finally, there is a fourth, related reason why judges may have found filmic evidence difficult to resist. This has to do with the conception of what kind of evidence courts prefer, and the implicit epistemology of legal evidence. Our system of rules governing the admissibility of evidence rests upon a set of basic assumptions, and fundamental among them is that we prefer that proof which comes closest to direct sensory perception. We have built a regime of legal evidence that is deeply Lockean, that assumes

169. This is not to say that the law and fiction operate in different realms; in fact, as Sherwin claims in the opening of his recent book on popular culture and law, "The law is shot through with fiction." SHERWIN, WHEN LAW GOES POP, supra note 19, at 3.

170. There is in fact a large recent literature analyzing the trial as a process of narrative construction. See, e.g., BENNETT \& FELDMAN, supra note 61; Pennington \& Hastie, supra note 61 . Even the Supreme Court has given a nod to the critical role that the making of narratives plays in the trial process. See Old Chief v. United States, 519 U.S. 172 (1997) (arguing that "a syllogism is not a story," that the jury expects stories, and that parties have the right to present their evidence in a compelling way). 
that knowledge must derive from the experiences of the senses. ${ }^{171}$ Hence, as a general rule, witnesses can testify only to things about which they have personal knowledge. And even if they have personal knowledge they must testify only to their perceptions - they are to report what they saw or heard directly, without gloss or interpretation. ${ }^{172}$ As Robert Burns describes it in his recent book on the trial as a cultural form, our legal system requires, as "more a first principle than a rule of evidence," that the jury hear "an artificially stripped-down, value-free account of the witness's perceptions." 173 Why this emphasis on direct perception? According to Burns, the typical explanation ("the received view") is that it contributes to the functioning of the rule of law, by giving the jury the basic building blocks for their decision in a form that makes it less likely that the jury will simply adopt the value judgments or conclusions of the witnesses. ${ }^{174}$

This explanation is clearly part of the story. But equally important is that what we are striving for, our ideal form of evidence, is that which will somehow give the jury direct access to the past: genuine knowledge, whatever that is, of what actually occurred. In this sense, the trial and the reenactment share an important similarity. Both aim to produce knowledge of a past event, knowledge that counts as true despite the inability of both trials and reenactments to capture the past directly. (We shall return to this similarity shortly.) And implicit in the rules of evidence is the belief that this knowledge is most likely to emerge from that evidence which is closest to the event itself-a direct eyewitness rather than a second-hand account, or an immediate description of what happened rather than a later one made after the witness had time for reflection. Legal scholar Kim Scheppele has invoked a wonderful metaphor for precisely this point: We strive to reach ground-zero, the physical and temporal location of the events that gave rise to the litigation. In her words,

The point of American evidence law is to enable the reproduction of the ground-zero moment and its aftermath to assess what truly happened. ... [G]round zero is the moment when "the trouble" occurred and the law of evidence strives to admit facts that were generated as close in time and space as possible to the moment when this trouble happened. ${ }^{175}$

Since the jury can't see the ground-zero moment for itself, we want the

171. JOHN LOCKE, AN ESSAY CONCERNING Human UNDERSTANDING (Peter H. Nidditch ed., Oxford Univ. Press 1979) (1690).

172. These conceptions are embodied in the Federal Rules of Evidence, but they come from common-law conceptions of admissibility. See FED. R. EVID. 602, 701

173. ROBERT P. BURNS, A THEORY OF THE TRIAL 20-21 (2000).

174. Id. at 21 .

175. Kim Scheppele, The Ground Zero Theory of Evidence, 50 HASTINGs L.J. 321, 322 (1998). 
jury to see and hear the next best thing: the direct sensory report of percipient witnesses, those who were in fact at ground-zero.

We have detailed so far two basic epistemological assumptions built into our rules of evidence: first, a preference for direct perception, and second, a preference for direct perception of the underlying events themselves, the ground-zero moment. But there is a third assumption as well, not quite so explicit in the evidence rules but equally real. And that is, quite simply, that among various forms of sense perception, seeing is best: that visual perception is both most authoritative and most persuasive. ${ }^{176}$ This preference is implicit, not explicit. No rule avows the primacy of the visual. Nevertheless, we can recognize it in a variety of ways: in the far greater attention paid to issues of eyewitnessing than earwitnessing; in the assumption that juries can judge credibility in part because they see the witness's demeanor; in the dominance of visual metaphors; and, perhaps especially, in the widespread use of visual evidence. ${ }^{177}$ One advocacy manual describes our fixation with evidence that can be seen as

"the wax museum" effect. People are fascinated by the real thing. The bullets that were found lodged in the victim's heart, the actual handwritten memorandum that was used to seal the agreement, the remains of the automobile gas tank that ruptured on impact burning the occupants of the car.... Until we see something tangible, [the event] is something that did not happen, or at least did not happen to real people. ${ }^{178}$

It isn't real until we see it. This, at last, brings us back to films as evidence. Films offer an especially powerful medium for making experience seem real: to watch a film of an event or occurrence provides the almost-illusion of having been there ourselves. In contemporary courtrooms, there are, on occasion, films that actually do capture ground zero: videos taken at the scene itself, capturing the moment in question for posterity and for courtroom scrutiny. ${ }^{179}$ Although there were not such films in the 1940s courtroom, the surveillance films do offer a kind of access to ground zero. They do not show the scene of the plaintiff's injury,

176. Whether this is a legal preference or simply the byproduct of a more general cultural belief in the primacy of the visual is not important for our purposes. On the traditionally central role of visuality in law and culture, see Bernard Hibbits, Making Sense of Metaphors: Visuality, Aurality, and the Reconfiguration of American Legal Discourse, 16 CARD. L. REV. 229 (1994) (arguing that vision has been central to law, but that aurality is now growing more important). On the hegemony of vision in modernity (and the existence of an anti-visual discourse), the classic work is MARTIN JAY, DOWNCAST EYES: THE DENIGRATION OF VISION IN TWENTIETH CENTURY FRENCH THOUGHT (1993).

177. See generally Hibbits, supra note 176, at 241 .

178. Id. (quoting Ashely S. LIPSON, ART OF ADVOCACY: DEMONSTRATIVE EVIDENCE $\S 2.02$ (1994)).

179. Of course, whether these films actually make the legal determinations clear or easy is another question altogether, as the Rodney King incident and its aftermath powerfully shows. 
but they do show the plaintiff him or herself, captured on camera during an ordinary day, showing the "real" plaintiff going about his or her business. But more generally, filmic evidence lets the jury see matters for itself; it turns the spectators into virtual witnesses.

Of course, these points elide a central question: Should the jury believe what is before its eyes? Film as a medium simultaneously reflects a belief in the primacy of the visual and challenges it. The experience of film watching is affectively powerful, and this power comes, in part, out of how genuine-seeming, how real, a film can seem. And yet a film is directed, staged, edited, acted-it is an elaborate production, an artifice that nonetheless feels real. As Siegfried Kracauer once famously claimed, "what the camera captures seems more real than reality itself." 180 The point, however, is that film as a medium plays to some of the significant assumptions embedded within our rules of evidence, and it has the added advantage of letting the jury see for itself.

Of course, it is precisely the way in which film seems real that makes it simultaneously powerful and dangerous. Through the medium of film, the real and the image can become so inextricably intertwined that jury members watching a film may forget the present of the courtroom to enter the past of the crime, or put aside their own identities to identify with an imagined witness. At the same time, they may see the reenactment of a crime or event as somehow more real than the original, and their viewing of it as somehow more legitimate than a mere witness's account-more real and more legitimate, that is, because of the heightened attention to the subject a film can provide, because of the heightened opportunity to see more carefully, more effectively, more conclusively. But despite these dangers-reflected precisely in Wigmore's warning as well as judicial concerns about the spectacular-judges may have felt that films simply could not be kept out. As a medium that gave the jury direct sense perception of relevant matters, that let them see events for themselves, it may have seemed too powerful, too persuasive, too appealing, to exclude.

\section{CONCLUSION}

This final argument, that films were an appealing form of evidence precisely because they give the viewer such a powerful perception of really being there, of witnessing, of approaching ground zero, takes us to our concluding point: that there is in fact a significant affinity between the filmed reenactment, as a cultural form, and what takes place in the courtroom.

If, as Richard Sherwin has recently argued, the "symbolic drama" played out by trials casts jurors into "a mythic space and time," where

180. Siegfried Kracauer, Theory of Film: THE Redemption of Physical Reality 23 (1960). 
"ordinary conventions drop away together with the ingrained habits of thought, feeling, and belief that maintain them," then surely the use of filmic evidence plays a part in this casting. ${ }^{181}$ Sherwin's description of a trial resembles, in fact, the ideal cinematic experience as constructed by Hollywood. In both, the viewer is asked to leave the circumstances of her own world behind in order to enter as fully as she can into the "virtual" world before her. In both, she is invited to see much more attentively than she does outside the perimeters of their spaces. In film, as in a trial, reality becomes compelling, not because it is ordinary, but because it is suddenly strange - because it invites the viewer to watch with an extra-ordinary kind of attention.

While films and trials may have certain parallels, our claim is more particular: that trials are in fact a kind of reenactment. In a filmed reenactment like Northside, typically a singular, largely consistent version of events unfolds on screen, ensuring that the audience, whether they sit in a court of law or a theater, reads the evidence in a certain way. ${ }^{182}$ By contrast, within a trial, multiple reenactments of the past compete. Each side offers its story, and the verdict is a judgment about which reenactment is more persuasive. The verdict affirms one side's story as the more plausible one, the one that bears a better correspondence to reality. Moreover, as evidence scholar Charles Nesson has persuasively argued, the verdict is not seen, in the end, as a comment on the strength or weakness of the evidence; rather, it is taken to be a judgment about what "really" happened. ${ }^{183}$

The key point is that both reenactments like Northside and the stories told at trials are, aspirationally, substitute depictions of what actually occurred. The reenactment and the representations presented at a trial both endeavor to stand in for the real. They do not do this through misrepresentation: They do not claim to be a literal depiction of what happened, but rather, acknowledge explicitly that they are retellings. They do not give us direct access to ground zero, but they nonetheless give us the essence of ground zero. The claim of a reenactment like Northsidethat which makes it a reenactment rather than just a fictional story inspired by real events-is that it is true to the actual past in all the ways that count. (Note that in this sense a reenactment's relation to the actual is, in fact analogical: Like an analogy, the reenactment claims to correspond to the real in the ways that matter, without professing an identity between the reenactment and the event itself.) Similarly, an attorney making a closing

181. SHERWIN, WHEN LAW GOES POP, supra note 19, at 50-51.

182. Of course, some films are in fact about the problem of perception and interpretation, and generate multiple versions of events precisely to illustrate the incomplete nature of perception and the fragility of memory: any list of such films would start with RASHOMON (Daiei 1950). For a thorough analysis of Rashomon as a socio-legal text, see Kamir, supra note 19.

183. Charles Nesson, The Evidence or the Event? On Judicial Proof and the Acceptability of Verdicts, 98 HARV. L. REV. 1357, 1357 (1985). 
argument endeavors to make the factfinders feel that they know what must have occurred even though they were not there. Reenactments and representations at trials become, at least in part, our account of what happened, even though we know that they do not give us transparent access to the events themselves. ${ }^{184}$ In fact, if they fail to become substitute depictions of the actual, they are failures in their own terms. The filmed reenactment that strays too far from reality loses credibility; it becomes at best, fiction, at worst misleading or propagandist. ${ }^{185}$ The trial verdict that cannot stand as a judgment about what actually happened can become a social problem, leading to cynicism about legal process (think O.J. Simpson) or in the extreme, unrest or riots (think Rodney King).

This excursion into films as evidence and the deep affinity between the reenactment and the trial itself has taken us some distance away from Northside itself. But it is worth nothing that Northside is itself a successful reenactment of just such a failed trial. That is, Northside tells the story of a verdict that in the end could not be believed as an account of what really happened. By the end of the film, Wiecek's conviction cannot stand, for it is no longer a plausible judgment about what actually occurred in that speakeasy so many years before. Note, however, that Wiecek's conviction does not simply collapse under its own weight: It takes an investigative reporter's diligent effort to bring forth the evidence that shows the mismatch between the verdict and reality. In this sense, Northside is an unusual reenactment: It is not merely, or even primarily, the story of a crime or the story of a trial. Rather, it is the story of the making of a story out of the crime and the trial. It is a reenactment of the making of a narrative, a narrative that revealed the original judgment of guilt to be nothing more than fiction.

If Northside's starting point is a trial in which the verdict and reality failed to correspond, as a reenactment the film largely succeeds. We do not mean by this to make an aesthetic judgment, but rather a practical one: Though Northside is not terribly well known, it seems nonetheless fair to say that it is all that remains of the original story of Joseph Majczek's wrongful conviction. The film has come to stand in for what really happened, and, with the passage of time, even the fictional photograph that the film uses to generate both a climax and evidentiary certainty has, on occasion, been seen as real. For example, in an annual report in 1994, a journalism foundation used Northside to illustrate the power of photographic evidence in a pre-digital era-and in a delicious irony, given

184. The film Boomerang makes this point explicitly. The reenactments within the film show the film's viewers all that they can ever know about what really happened-which is mostly that they cannot really know what happened. The film shies away from its epistemological skepticism, however, by implicitly (and unfortunately) giving the viewers an alternative (and never fully proven) theory of the crime.

185. This is precisely the debate, for example, over some of Oliver Stone's films, such as NixoN (Hollywood Pictures 1995), or JFK (Warner Brothers 1991). 
that it was, after all, a report on the future of journalism, simply assumed that the photograph had really existed:

In the 1948 film Call Northside 777, Jimmy Stewart obtained an innocent man's freedom from prison by means of the latest technological advance - the Associated Press Wirephoto.... In real life, Chicago Times reporter James McGuire received a Pulitzer Prize for the reporting on which the movie was based. His hard work-his clever use of the latest technology - succeeded in freeing the unjustly convicted Joe Majczek from prison, where he had served 11 years for a crime he didn't commit.

In the 1940s, modern technology performed the miracle of transmitting irrefutable photographic evidence almost instantaneously from one location to another. In the 1990s, technology has made it possible for all existing means by which information is imparted from one human being to another-sounds, images, printed wordsto be converted into digital form-the $0 \mathrm{~s}$ and $1 \mathrm{~s}$ used by computers.... Would the photo McGuire used to prove Majczek's innocence prove anything at all anymore? ${ }^{186}$

We ought not to overinterpret an annual report. But still, this example shows how, especially with the passage of time, the reenactment can indeed become the real thing, or at least, all that remains of it.

Creating a believable story of the past is the raison-d'être of reenactments and trials alike. Both the stories told at trials and those told in reenactments like Northside admittedly provide only a partial, subjective, mediated, and even fictional account of what occurred. They cannot and do not claim truth in any grand sense, but their purpose is truth nonetheless: Both verdicts and reenactments attempt to capture the past in the ways that matter most. Recognizing this affinity between the trial and the reenacted film provides one final reason for why judges were reluctant to engage in a sustained critique of film as evidence: Perhaps such a critique would lead to a reflective examination of the trial process itself, exposing the theater of proof as, well, theater.

186. The RoBERT R. MCCORMICK TRIBUNE FOUND., 1994 (JOURNALISM ProgRAM), available at http://rmtf.org/journalism/j94ar.htm. Note also that McGuire did not in fact receive a Pulitzer for his reporting on Majczek, though he did receive several other awards. See supra note 13. 